\title{
The adaptive cycle and the ecosystem services: a social-ecological analysis of Chiloé Island, southern Chile
}

\author{
$\underline{D a n i e l a}$ C. Pérez-Orellana $^{1}$, Luisa E. Delgado ${ }^{1,2}$ and Victor H. Marin $^{1}$
}

\begin{abstract}
We used the adaptive cycle as a heuristic to conceptualize the changes in ecosystem services between its phases (growth, conservation, collapse, and reorganization) for Chiloé Island (southern Chile), analyzed as a social-ecological system. We generated hypothetical relationships between services and phases based on literature articles, testing them with secondary databases for 18262016 and interviews with local actors. Results show that the island is currently either in a late conservation phase or already in a collapse phase. Only provisioning ecosystem services corresponded with the proposed phases' relationships, while regulation-maintenance and cultural services showed long-term decreasing trends. We discuss cross-scale interactions and political centralism as the main factors preventing a local adaptive scheme that may start a reorganization phase.
\end{abstract}

Key Words: adaptive cycle; Chiloé Island; collapse; ecosystem services; panarchy

\section{INTRODUCTION}

The adaptive cycle's heuristic conceptualizes the changes of complex systems on four consecutive phases (Holling 2001): (1) growth, (2) conservation, (3) collapse or creative destruction $(\Omega)$, and (4) reorganization $(\alpha)$. The first two are slow, predictable, and analog to ecological succession. The last two are fast, unpredictable, and critical to determining the system's destiny.

Three dimensions define the phases: (1) potential, or the range of accumulated resources, (2) connectedness, or the degree of connection between variables and internal controlling processes, and (3) resilience, which depends on the previous two dimensions (Holling 1986, 1987, 2001, Holling and Gunderson 2002). A resilient system should move through all four phases, or skips one (Walker et al. 2006), without being caught in one phase by obstacles or traps (Fath et al. 2015), especially in the collapse phase $(\Omega)$, where rules, value systems, and interactions between peoples and ecosystems become dysfunctional (Nayak et al. 2014).

Panarchy (Gunderson and Holling 2002) refers to the hierarchical structure of the interconnections of complex systems, explaining their dynamic as a nested set of adaptive cycles (from small and fast to large and slow scales), which determines the system's sustainability (Holling 2001). Recognizing the suitability of the panarchy theory as a heuristic of complex systems organization, many authors have investigated the linkages between adaptive cycles in social systems and ecosystems, focusing on cycles of destruction and renewal (Carreiro and Zipperer 2011, Allen et al. 2014). According to the panarchy theory, complex adaptive systems have a cross-scale structure resulting from the positive and self-reinforced interactions between several scales (Holling and Gunderson 2002, Angeler et al. 2011). Although there may be many connections between scales, Holling (2001:397 and 398) emphasizes two of them: "revolt" (from small and fast cycles to large and slow) that occurs when the former is in a creative destruction phase and the latter in a conservation phase, and "remember" (from large and slow cycles to small and fast), which may impact the reorganization of the latter by the conservation dynamics of the former (Holling 2001, Holling and Gunderson 2002, Baral et al. 2010, Williams et al. 2019, Joseph and McGregor 2020). Scales, for this purpose, can be temporal, spatial, jurisdictional, and institutional, among others. Abel et al. (2006) propose that an excess subsidy from higher panarchy scales may increase the lower scales' dependency, reducing their selforganizing capabilities. Therefore, exploring cross-scale interactions, such as obstacles or traps (Haider et al. 2018, Nahuelhual et al. 2019), is essential to understand the system's dynamics.

\section{Ecosystem services and the adaptive cycle}

Ecosystem services (ES) are the benefits that people get from ecosystems: (1) provisioning, (2) regulation and maintenance, and (3) cultural (Haines-Young and Potschin 2018). They result from the functionality of the ecosystem, and changes in its structure and functions will affect them (Haines-Young and Potschin 2010). Although the ES conceptual framework can be used on any scale, it is commonly applied within regions where the local social subsystem interacts with the ecological subsystem (Binder et al. 2013). However, current globalization makes the ecological dynamics and the supply of ES vulnerable to large scale processes (Laterra et al. 2016).

Walker et al. (2002) propose a relationship between ES allocation and the system's state. Dick et al. (2011), analyzing a diversity of conceptual frameworks through a literature review, show that published articles relate the adaptive cycle only to the natural capital. Mhango and Dick (2011), analyzing developing countries, propose that the ES concept and the panarchy framework could be useful policy tools. Other authors have shown that alternative configurations during a reorganization phase $(\alpha)$, or regime shifts, produce changes in the provided services (Bohensky 2008, Biggs et al. 2012, Chaffin et al. 2016). So, differences in ES provisions can also characterize the phases of the adaptive cycle (Laterra et al. 2016). Burkhard et al. (2011) and Delgado et al. (2019a) propose relationships between the use of

${ }^{1}$ Laboratorio de Modelación Ecológica, Departamento de Ciencias Ecológicas, Facultad de Ciencias, Universidad de Chile, ${ }^{2}$ Fundación CTF, Santiago, Chile 
Table 1. Hypothetical relationships between the phases of the adaptive cycle and the ecosystem services based on Delgado et al. (2019a) and Burkhard et al. (2011).

\begin{tabular}{|c|c|c|}
\hline Phases of the adaptive cycle & Delgado et al. (2019a) & Burkhard et al. (2011) \\
\hline $\begin{array}{l}\text { Creative destruction or collapse } \\
(\Omega)\end{array}$ & Decrease in all type of services. & Decrease in all types of services. \\
\hline $\begin{array}{l}\text { Reorganization } \\
(\alpha)\end{array}$ & $\begin{array}{l}\text { Unpredictable, because of the } \\
\text { emergence of new components and } \\
\text { relationships between the elements of } \\
\text { the social-ecological system. Increase } \\
\text { in the diversity of services. }\end{array}$ & Increase in regulating services. \\
\hline $\begin{array}{l}\text { Exploitation or rapid growth } \\
\text { (r) }\end{array}$ & Increase in all ecosystem services. & $\begin{array}{l}\text { Increase in ecosystem services. Some } \\
\text { services, e.g., cultural, may behave } \\
\text { differently. High uncertainty. }\end{array}$ \\
\hline $\begin{array}{l}\text { Conservation } \\
(\mathrm{K})\end{array}$ & $\begin{array}{l}\text { Maintenance of main services from } \\
\text { the rapid growth phase. Decrease in } \\
\text { the variety of services. }\end{array}$ & $\begin{array}{l}\text { Highest values for most ecosystem } \\
\text { services. High uncertainty. }\end{array}$ \\
\hline
\end{tabular}

ES and the phases of the adaptive cycle that can guide empirical case studies on the coherence between both conceptual frameworks (Table 1).

Berkes and Folke (1998) define a social-ecological system (SES) as a bio-geo-physical unit, its social actors, and associated institutions. The dependency relationships between ES and the subsistence and quality of life of rural and ancestral communities in SESs are distinct for developing countries (Delgado and Marin 2019). For example, in the face of pollution or the local disappearance of species, people change their life strategies (Delgado et al. 2009). Thus, social-ecological resilience will depend on the social capitals, ecosystem structures, and processes, and the interaction between them analyzed through ES. Auad et al. (2018) propose that new ES will be easily incorporated during the reorganization phase $(\alpha)$, but they could have adverse effects if incorporated in other phases. Thus, merging the adaptive cycle and ES frameworks could improve the understanding of the SES's dynamic changes (Table 1). Furthermore, when analyzed at several spatial and temporal scales, panarchy opens the opportunity to contribute to the understanding of the systems' sustainability and to propose solutions for existing challenges to the system's sustainable management or governance (Elliff and Kikuchi 2015, Laterra et al. 2016, Auad et al. 2018, Delgado et al. 2019b).

\section{Chiloé Island as a social-ecological system}

The Chiloé archipelago (Fig. 1) is a group of islands located in southern Chile $\left(42^{\circ} \mathrm{S}-44^{\circ} \mathrm{S}\right)$, Pacific coast of South America, with Chiloé Island as its main component, accommodating 170 thousand people (INE 2017). Its environment consists mainly of rural human settlements within temperate forests and prairies and an interior sea where most productive and food gathering activities occur. From a cultural perspective, the island is a mixture of global society's components plus its traditional ethnicity (chilotes) originated from the syncretism between local MapucheWilliche people and Spaniard colonizers that arrived during the 16th century. We analyze Chiloé Island as an SES where its historical, social, and ecological components changed during the 20th century.

Chilotes have based their historical subsistence and well-being on artisan fisheries, shore food gathering, and the use of other
Fig. 1. Location of the study area (Chiloe Island) on the Chilean coast. The figure shows accepted aquaculture sites in Chiloé archipelago (Dataset date: March 2019). Coordinate system $=$ UTM 18S, datum $=$ WGS 84 .

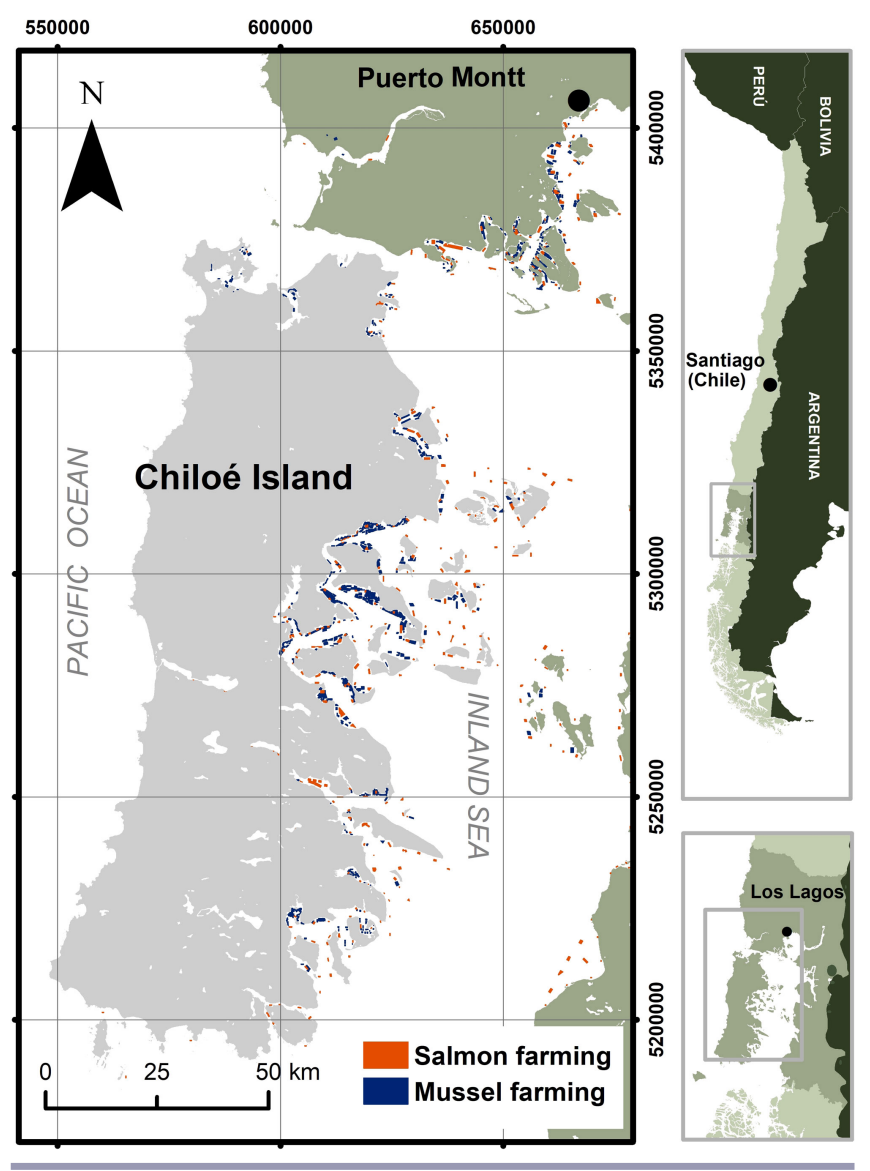

components from marine and terrestrial ecosystems (Mansilla Torres 2006), defining the island's historical social-ecological components. However, since 1969 the aquaculture industry, driven by global markets and the Chilean state intervention, 
Table 2. Main social drivers for the four phases of the adaptive cycle.

\begin{tabular}{|c|c|c|c|}
\hline Phase & Description & Drivers & References \\
\hline \multirow[t]{7}{*}{$\begin{array}{l}\text { Collapse or creative } \\
\text { destruction }(\Omega)\end{array}$} & $\begin{array}{l}\text { Some big external } \\
\text { perturbations may generate } \\
\text { collapses from any phase }\end{array}$ & $\begin{array}{l}\text { Unfavorable commerce for the dominant productive activity, } \\
\text { repeated setbacks affecting productive processes, e.g., outbreaks, } \\
\text { fires, plagues. }\end{array}$ & $\begin{array}{l}\text { Holling }(1987,2001) \text {, Walker } \\
\text { et al. (2006), Abel et al. (2006) }\end{array}$ \\
\hline & & Excessive external subsidies increase the connectivity of the social- & Vang Rasmussen and \\
\hline & & Cataclysms generating a loss of human capital (lives) and adverse & Holdschlag and Ratter (2016), \\
\hline & & $\begin{array}{l}\text { effects to the vulnerable rural population with cascading effects, e.g., } \\
\text { housing problems, damages to the provision of ecosystem services. }\end{array}$ & Zhang et al. (2018) \\
\hline & & Natural resources depletion, lack of human capital, ecological & Motesharrei et al. (2014), \\
\hline & & problems and economic stratification. & Tenza et al. (2017) \\
\hline & & Decrease of the benefits that people obtain from ecosystems. & This article \\
\hline \multirow[t]{2}{*}{ Reorganization $(\alpha)$} & $\begin{array}{l}\text { Generated mostly from a } \\
\text { growth }(\mathrm{r}) \text { or a collapse }(\Omega) \\
\text { phase }\end{array}$ & $\begin{array}{l}\text { Alternative productive activities increase in the social-ecological } \\
\text { system, especially those included within the legal system. }\end{array}$ & Abel et al. (2006) \\
\hline & & $\begin{array}{l}\text { People obtain new benefits from ecosystems. New successful } \\
\text { enterprises, replacement of native species by others with higher } \\
\text { monetary outcome. }\end{array}$ & This article \\
\hline \multirow[t]{2}{*}{ Growth (r) } & $\begin{array}{l}\text { Originated most likely from a } \\
\text { previous reorganization } \\
\text { phase }(\alpha)\end{array}$ & $\begin{array}{l}\text { Growing commercialization of a good and the stabilization of a } \\
\text { higher production rate than in the previous phase. }\end{array}$ & Beier et al. (2009) \\
\hline & & $\begin{array}{l}\text { People obtain larger benefits from ecosystems. Traditional practices } \\
\text { are changed because of technological innovation of productive } \\
\text { processes. Increase in social capital both union and bridge. }\end{array}$ & This article \\
\hline \multirow[t]{3}{*}{ Conservation $(\mathrm{K})$} & $\begin{array}{l}\text { It generates after a growth } \\
\text { phase (r) }\end{array}$ & Maintenance of SES high levels of organization. & Fath et al. $(2004,2015)$ \\
\hline & & Landscape homogeneity. Higher dependency on external factors. & Winkel et al. (2016) \\
\hline & & $\begin{array}{l}\text { People maintain their ecosystem' benefits. Economic and political } \\
\text { domination from national and global scales. Political-administrative } \\
\text { rules become more rigid. }\end{array}$ & This article \\
\hline
\end{tabular}

moved this isolated area into modernity. This process generated employment, infrastructure development, and changes in people's expectations and aspirations. It also forced a hybridization and commodification of chilotes culture toward tourism, pushing the island closer to the benefits and risks of globalization (Barton and Román 2016), generating ecological changes (Capriroli 2019, Paredes 2019). We used the adaptive cycle to interpret the socialecological changes of Chiloé Island for the period 1826-2016, driven by the question: Do changes in ES agree with the proposed theoretical relationships between both conceptual frameworks (Table 1)? We also studied the interactions between adaptive cycles at different scales to analyze their effects on Chiloé SES.

Pereira et al. (2018), discussing transformations for sustainability, state that there is "a dearth of literature ... in the diverse contexts of the Global South." We argue that, among other reasons, it is challenging to publish on sustainability issues without knowledge of the historical changes of the structure and functions of SESs. We have written this article as a contribution to that knowledge.

\section{METHODS}

Identification of the phases of the adaptive cycle and ecosystem services through a historical analysis of social-ecological events We analyzed the literature for drivers associated with the different phases of the adaptive cycle (Table 2). We then searched for these drivers through the Web of Science (WoS) looking for articles (1975-2018) using the syntaxis TITLE (Chiloe) AND THEME (Chiloe). We also used the Scopus database (1960-2018) using the same syntaxis. WoS generated 248 articles, Scopus 598 articles.
We selected articles related to ecological, social, economic, cultural, and anthropological studies, reducing to 54 articles for WoS and 97 for Scopus. Also, we analyzed local historical events in books, interviews, and thesis documents published by Chilean universities. Then, we used the information to identify the phases for Chiloé Island through a retrospective study of historical events, organizing them chronologically (1826-2016), and in three geographic scales (local, regional, and global). Finally, we defined the capitals for each phase (Appendix 1) to study the system's connectivity and adaptive capacity (Abel et al. 2006).

We also used the scientific literature and historical documents to identify terrestrial and coastal-marine ES (provisioning, regulation-maintenance, and cultural) used in Chiloé Island (Table 3). We classified each analyzed ES in three numerical categories (i.e., qualitative evaluation): scarce (0), low (1), and high (3) for each phase of the adaptive cycle. For example, in the case of the ecosystem service "use of ancestral cultural information" (cultural services; Table 3); Álvarez et al. (2008) shows high union social capitals and traditional practices at the beginning of our study period (1826-1959), maintained until the middle of the sixties when they started decreasing (Armando Bahamondes, personal communication, Dalcahue, Chiloé). Thus, we defined the first two phases 1826-1959 and 1960-1967, with a high value (3) and the next period with a low value (1). The author (Álvarez 2011) also states that traditional practices ended in 1980; consequently, we assigned a zero value to the next three phases. We used the same approach for all services in Table 3, using the generated values to analyze temporal ES changes using linear regression analyses (SPSS, Version 26, 2019). For that 
purpose, we treated the time sequence of phases (Appendix 1) as the explanatory, categorical, variable starting with 1 for the first period (1826-1959) up to 6 for the last (2007-2016). The dependent variable was the average value of each type of ES, considering all analyzed services (Table 3).

Table 3. Ecosystem services (ES) defined for Chiloé Island.

\begin{tabular}{|c|c|c|}
\hline ES type & Ecosystem & Service \\
\hline $\begin{array}{l}\text { Provisioning } \\
\text { Services }\end{array}$ & Terrestrial & $\begin{array}{l}\text { Coastal species harvest } \\
\text { Artisanal fisheries } \\
\text { Extraction of wood from native } \\
\text { forests } \\
\text { Bryophyte extraction } \\
\text { Extraction of wild plant fibers }\end{array}$ \\
\hline $\begin{array}{l}\text { Regulating and } \\
\text { Maintenance }\end{array}$ & Coastal-marine & $\begin{array}{l}\text { Salmon farming habitat } \\
\text { Mussel farming habitat }\end{array}$ \\
\hline Services & Terrestrial & $\begin{array}{l}\text { Productive and healthy land } \\
\text { (agriculture) } \\
\text { Productive and healthy land (animal } \\
\text { breeding) } \\
\text { Use of natural fertilizers }\end{array}$ \\
\hline Cultural Services & Both & $\begin{array}{l}\text { Use of spiritual information } \\
\text { (Chilote's mythology) } \\
\text { Use of traditional cultural } \\
\text { information } \\
\text { Use of ancestral cultural } \\
\text { information } \\
\text { Cultural tourism }\end{array}$ \\
\hline
\end{tabular}

Social validation of the current (2018) phase of the adaptive cycle of Chiloé Island

We conducted face-to-face interviews with local social actors ( $\mathrm{N}$ $=35$ ) to analyze their perception of the current (2018) phase of Chiloé's adaptive cycle (Appendix 2). Interviewees were academics $(\mathrm{N}=5)$, mussel and salmon farmers $(\mathrm{N}=11)$, tourism enterprises representatives $(\mathrm{N}=10)$, culture keepers $(\mathrm{N}=6)$, government employees and NGO members $(\mathrm{N}=3)$. Before the interview, the interviewer (one of the three authors of this article) described each phase of the cycle (see text in Appendix 2), evaluating the method's robustness by asking the interviewee to describe each phase. The investigator continued with the interview only when he/she was satisfied with the answers, otherwise redescribing the phases. We codified, for analytical purposes, interviewees' identified phase with an integer: reorganization phase $(\alpha)=1$, growth or exploitation phase $(r)=2$, conservation phase $(K)=3$, and collapse or creative destruction phase $(\Omega)=4$. We then analyzed their responses and differences through a oneway ANOVA with a significance $\alpha$ level $=0.05$ (SPSS, version 26, 2019). All interviewees signed informed consent.

\section{Panarchy and cross-scale interactions}

A panarchy comprises several adaptive cycles. We analyzed crossscales interactions affecting Chiloé Island SES using three cycles:

- Global (economic markets): this cycle generates processes affecting the other two cycles, such as telecoupling (Hull and Liu 2018), modifying regional, national, and even local cycles (Delgado et al. 2019b). Global processes may influence local fluxes of information, energy, and matter, people (e.g., emigration and immigration), financial capitals, services, and products (Hull and Liu 2018).
- National-regional (institutional-jurisdictional): this corresponds to the cycle that generates most political and administrative instruments (e.g., laws, programs, and decrees), especially in centralized countries like Chile.

- Local (social-ecological): this is the adaptive cycle hypothetically (Table 1) related to the local use of ES (Delgado et al. 2019c). It may show sudden or long-term changes producing depletion of natural resources and even social collapses (Burkhard et al. 2011).

Using the gathered information, we identified the elements, processes, and changes of each scale and the processes from one scale potentially affecting other scales.

\section{RESULTS}

\section{An adaptive cycle model of Chiloé Island SES}

We identified six main society-nature events (drivers) affecting Chiloé Island SES during the last 190 years (1826-2016; Fig. 2). The first event was the signing of the Tantatuco Treaty in 1826 that incorporated Chiloé Island to Chile. During this growth period, the main component was potatoes production, which made Chiloé Island the largest producer in Chile. The $9.5 \mathrm{Mw}$ Chilean 1960 earthquake, with Chiloé as one of its epicenters (second driver), generated a collapse phase $(\Omega)$, given the destruction it generated on local capitals (Appendix 1). In 1967 a reorganization phase $(\alpha)$ started with mussel farming in wooden rafts on Chiloé's coastal zone and the subsequent diversification of economic activities (third driver). The fourth driver was the onset of Chile's neoliberal economy in 1974, generating a growth phase (r) lasting 22 years. A conservation phase $(\mathrm{K})$ began when Chile became the world's first salmon exporter in 1996. The massive installation of the salmon industry in Chiloé inland sea generated a system's rigidity trap because of increasing economic dependencies on two commodities (mussels and salmons). In 2007 the system entered into a collapse or creative destruction phase $(\Omega)$, triggered by the beginning of a salmon industry crisis related to an outbreak of infectious salmon anemia (ISA). The disease made salmon unmarketable, generating the closure of infected coastal farms and processing plants on land. The societal effect was a high local unemployment rate, especially between 2008 and 2010. Since then, the collapse phase has worsened because of numerous socioeconomic and social-ecological crises. Chiloé's coastal zone has experienced several harmful algal blooms during this phase (2007, 2009, 2016, and 2019; León-Muñoz et al. 2018), generating the closure of mussel farms, preventing people from obtaining shore resources, and forcing the government to increase auditing of the aquaculture industry. These events and processes produced a whole island social protest in May 2016, called "chilote's May" (Mayo chilote; Vargas 2016). The protest made evident the close relationship between the services of the coastal marine ecosystems and chilote's well-being, generating a response from the government of subsidies and bonds to reduce temporarily people's income problems.

\section{Phases and ecosystem services}

The historical analysis of ecosystem services showed that only provisioning services agreed with the hypothetical phases' relationships (Table 1) of the local (social-ecological) adaptive cycle of Chiloé Island (Fig. 3A). On average, provisioning services increased during the reorganization $(\alpha)$ and growth (r) phases, but they did not increase during the conservation phase $(\mathrm{K})$ and 
Fig. 2. Chronology of the main drivers within the phases of Chiloé Island's adaptive cycle for the period 1826-2016.

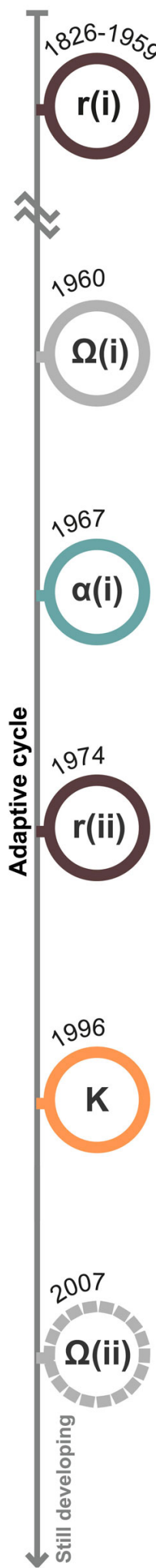

I Incorporation of Chiloé to Chile: The signing of the Tantauco Treaty, between the Chilean and the Spanish I governments, annexed the Chiloé archipelago to Chilean national territory. However, historical documents show that the State left the island abandoned.

1850 Chilotes emigrate to Patagonia because of the emergence of industrial activities in southern areas (e.g., sea wolf hunting and woodcutting).

1900 Decrease of lumber activities in Patagonia triggered the return of chilotes to the island, where they worked on potatoes agriculture. This process transformed Chiloé into one of the largest potatoes producers until 1950.

9.5 Mw earthquake in Chile, with epicenter at Chiloé: it generated an increase in coastal wetlands after the subsidence of coastal zones. It also generated a near-extinction of mussels (Choromytilus chorus) and other mollusks and an increase in human emigration.

1950 Problems with the culturing of potatoes (Solanum tubersum) because of the potato blight disease until 1964.

1960s Beginning of Highway 5 construction, which will cover the island from north (Ancud) to south (Quellón). People started building houses close to the new roads instead of only in the coastal zone (former maritime connection) and started to use land transport.

Mussel culturing starts in Chiloé coastal zone: mussel culturing, with the economic help of the Chilean I government, starts with seed collection of mussels (Aulacomya atra), increasing the diversity of economic activities and the use of ecosystem services. There is an increase of social responses including the generation of mutual cooperation networks, cooperatives, and new extraction activities both in the coastal zone and inland.

1962 Agrarian reform Law ( $\left.N^{\circ} 16.640 / 1967\right)$ in Chile until 1973.

1969 Foundation of the dairy cooperative (CHILOLAC), currently known as "Sociedad de Agrolácteos de Chiloé S.A".

Establishment of the neoliberal economy in Chile impacting on Chiloé development: there is a decrease in the self-sufficiency of the human population because of the changes produced by emergent production I industries (mussel exporting and salmon farming). It ends the free access to the coastal zone and several

I traditional ancestral activities such as the fishing pen from Huilliches disappear.

1980s There is an increase in forestry exploitation, mostly by matchwood industries. Chile becomes the third main worldwide exporter of matchwood, coming mostly from native trees.

1989 A nonregulated diversification on land use starts, with the support of the Chilean government (Institute for the Development of Agriculture and Cattle Farming, INDAP). Forestry plantations increase 48.7\% between 1989/1990 and 1997/1998.

Globalization of salmon production: Chiloé becomes the main salmon production zone worldwide.

1997 Accusations made against Chilean farm companies, because of disloyal competition, by the Chamber of Commerce of the United State of America.

1998 First pieces of evidence of changes in terrestrial ecosystems due to the modification of Chilean silviculture law (D.L. 701/1974). Massive exploitation of moss (Sphagnum sp.) and peat from peatland ecosystems in Chiloé.

2000 Chiloé starts receiving an increased number of tourists because of the declaration of its churches as World Patrimony Sites from UNESCO.

Outbreak of Infectious Salmon Anemia Virus (ISAV) in Chiloé: a severe sanitary crisis affects the salmon industry, heavily influencing its economy, which triggers a socioeconomic crisis due to the sudden increase in unemployment. Simultaneously, the local milk industry (CHILOLAC) goes bankrupt.

2007 Harmful algal blooms (HAB) become more permanent in Chiloé coastal ecosystems, highlighting the 2009 and 2016 events.

2012 FAO declares Chiloé as world importance agricultural patrimony (SIPAM), and in 2015, it expresses concern about the low recruitment of mussels on Chiloé's natural banks.

2013 Chile becomes the second worldwide mussel producer.

2016 Social protests, known as Chilote's May, develop after strong HABs and the death of mussels on Chiloé's beaches. The Chilean government decides to generate an economic bonus to help the local population. 
Fig. 3. Qualitative changes in ecosystem services of Chiloé Island for the period 1826-2016. (A) = provisioning services, (B) = maintenance and regulation services, $(C)=$ cultural services. Straight lines and black circles represent the average numerical category value for each service type. Dashed lines for (B) and (C), correspond to the $95 \%$ confidence limits for the linear regressions. They do not appear in (A) because ecosystem services (ES) time changes did not fit a linear regression.

(A)

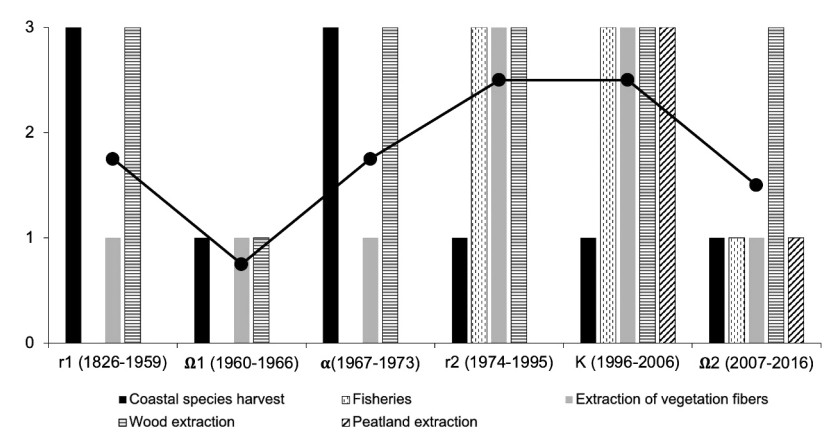

(B)

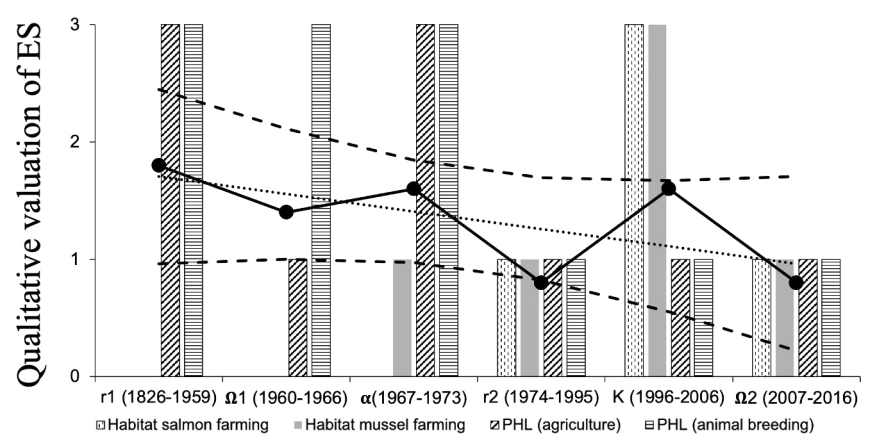

(C)

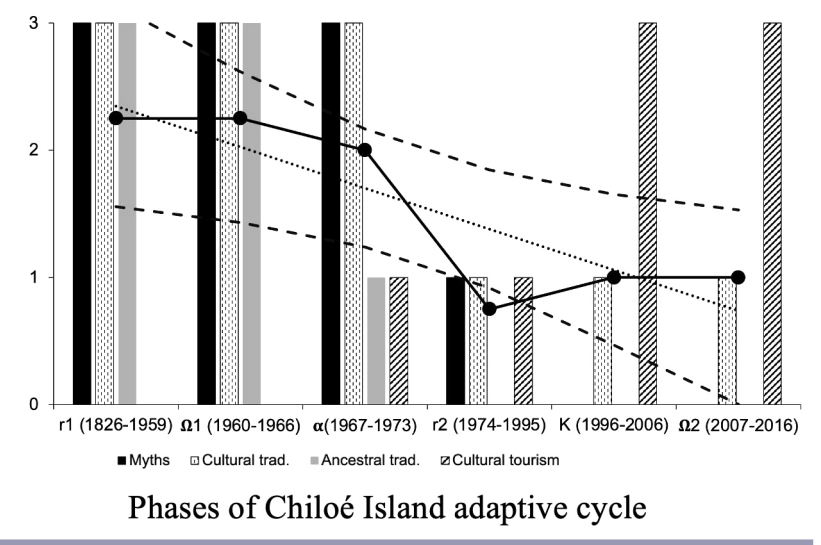

decreased in both collapse phases $(\Omega)$. Changes to the other two types of services showed linear decreases in time, unrelated to the adaptive phases. Regression for regulation and maintenance services was significant at $\mathrm{p}=0.1$ while for cultural services, $\mathrm{p}=$ 0.02. Cultural services analysis showed that starting in the second growth phase (r2; Fig. 3C), cultural tourism replaced myths and cultural and ancestral traditions.
Local validation of the current phase of Chiloé Island socialecological adaptive cycle

Interviews results showed that $51.4 \%$ of the interviewees perceive that Chiloé Island is currently in a collapse phase $(\Omega)$, and $42.9 \%$ defined it in a conservation phase (K). Still, $80 \%$ of the latter described it as a late-stage, that is, with the SES near its collapse. None of the interviewees perceived the system in a growth phase $(\mathrm{r})$, and only $5.7 \%$ perceived it in a reorganization phase $(\alpha)$. We did not find significant differences in the perception among groups of interviewees $(\mathrm{p}=0.74)$.

Interviewees defining the current phase as a late-stage conservation phase $(\mathrm{K})$ mentioned arguments such as the following:

- "Governmental inspection started only when the crisis developed."

- "We are at the limit of cultural collapse."

- "Laws have not helped to maintain the environment."

• "Collapse could occur soon, especially because of garbage."

Cross-scales interactions leading to the current collapse phase

We developed a panarchy model for Chiloé Island based on interactions among the three cycles described above (Fig. 4). We propose that the local social-ecological cycle is currently in a collapse phase $(\Omega)$ with a decrease in ES. We did not define the chronology of the next cycle (regional-national scale for the Chilean institutional-jurisdictional coupling). Nevertheless, based on the literature review, documents, and the analysis conducted by Delgado et al. (2019c), it is currently in a late conservation phase $(\mathrm{K})$ because of rigid political structures. These structures facilitated the introduction and industrialization of salmon farming in the Chiloé coastal zone in 1991 (Chilean Fisheries and Aquaculture Law $N^{\circ}$ 18.892), followed by a clustering process with the salmon industry, generating a production chain between providers and the enterprises within the region. The industry then offered economic subsidies and loans to all those interested in participating in the production/ export process, making other ways of life (agriculture, wood harvest) almost nonviable (Bustos and Román 2019). For the third and higher cycle (global scale of economic markets), we suggest that the adaptive cycle is crossing what Holling and Gunderson (2002:1057 [Kindle edition]) call a "front loop" stage. That is, "the slow, incremental phase of growth and accumulation" from a growth phase (r) to a conservation phase (K; e.g., UN Department of Economic and Social Affairs 2020).

The global cycle's main event was the Chile-Japan agreement that introduced Pacific salmon to Chiloé in 1969 (Amtmann and Blanco 2001). This event reinforced the local reorganization phase $(\alpha)$, introducing aquaculture activities based on existing capital (cultural and natural) from the Chiloé Island SES that were disarticulated by the 1960 cataclysm. Barton et al. (2013) propose that salmon farming relates to global processes (e.g., investments, technology, and sales), but only weakly to the local environment, exploiting resources and human capital, leaving all local development responsibilities to public authorities. Also, in 1969 Chile did not have legislation, regulation, and planning for its development. We propose that this cross-scale process is a "remember" connection that enables the reorganization by the 
Fig. 4. Conceptual, three-scale, panarchy model for Chiloé Island social-ecological system (1826-2016).

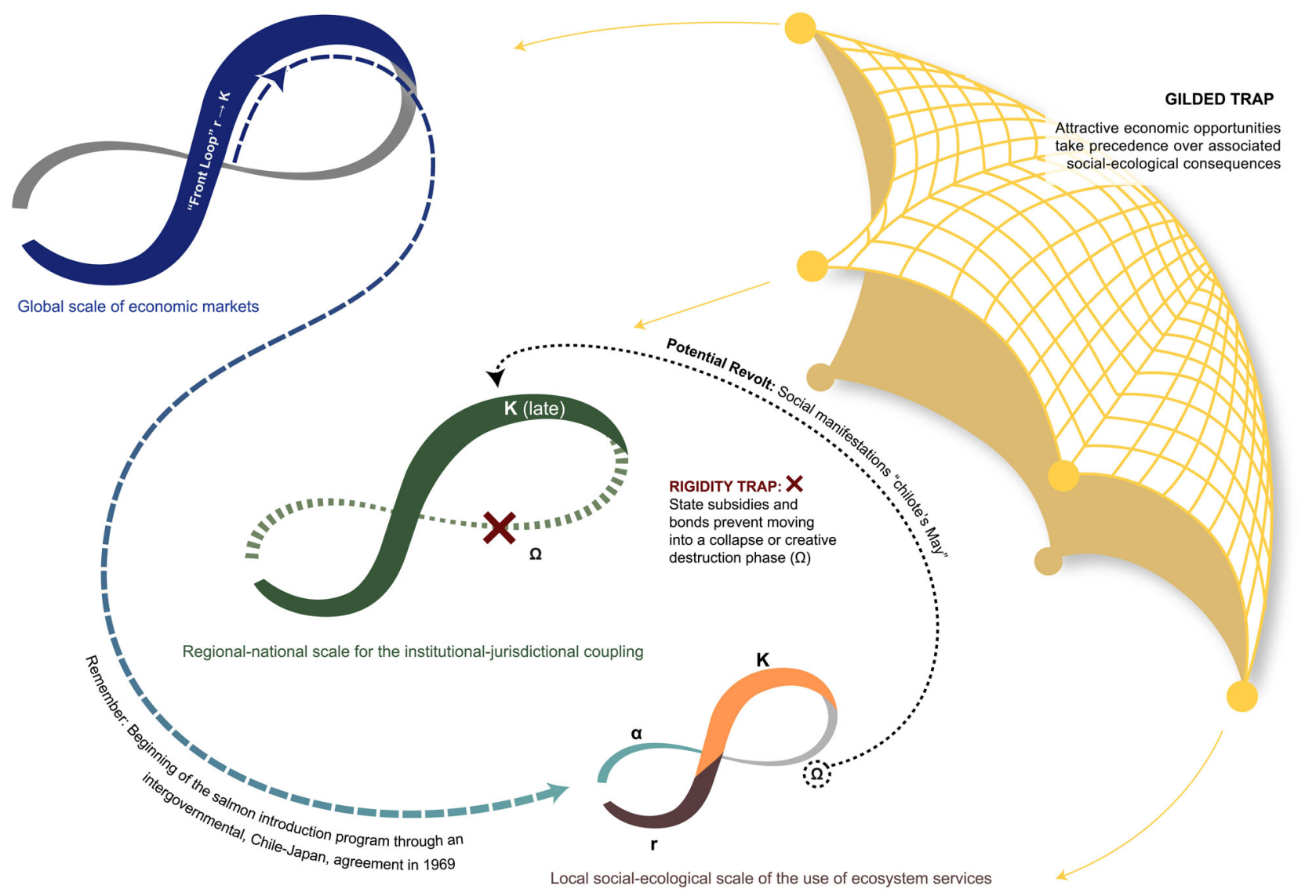

accumulated potential of the global scale cycle (Holling 2001). This cross-scale connection was established from the global to the local cycle, without connections with the regional-national cycle.

The Chilean fisheries/aquaculture law (Law No 18.892 , September 1991) was then generated within the institutional-jurisdictional cycle, facilitating economic activities and foreign capitals' entry, following the neoliberal logic in 1973. This economic model maintained the local adaptive cycle's growth phase (r; Fig. 2). However, mussel and salmon farming clusters outcompeted local, traditional, economies recruiting labor and leaving the local economy under the umbrella of few enterprises, generating an economic dependency of chilotes. Under these conditions, some authors have described the Chilean state's role as permissive (Cabello et al. 2018). Nevertheless, local traditions started getting lost in later years (2008-2010) when the government increased coastal regulations requiring fishing permits and assigning quotas even for traditional activities such as macroalgae and seafood harvest (Pavez 2015, Bustos and Román 2019).

The 2007 ISA virus crisis in Chiloé's coastal zone was one of the events that showed the strong dependency of local, traditional chilotes, and the aquaculture industry on coastal ecosystems. The ISA virus is not endemic of the Chilean coast, so its presence in Chilean waters resulted from cross-scale interactions
(Barrionuevo 2011). Less than a decade after the ISA virus crisis, people from Chiloé Island participated in massive protests, triggered by the dumping of 4600 tonnes of rotten salmon into the ocean, with the Chilean government's consent. This event could, in theory, have produced a "revolt" cross-scale effect in the institutional-jurisdictional cycle, which could have generated a collapse phase $(\Omega)$. However, toward the end of the protests, the Chilean government declared Chiloé as a "zone of catastrophe," offering a one-time economic bonus of US\$150 to each affected family (Mascareño et al. 2018). Such a subsidy worked as a rigidity trap, maintaining the institutional-jurisdictional cycle in the conservative phase $(\mathrm{K})$ and avoiding it from entering into a collapse phase $(\Omega)$. On 25 October 2020 , Chileans will vote to decide if they want a new constitution, to decrease, among other things, the current centralism, which could disentangle the rigidity trap $^{[1]}$. Also, we propose another rigidity trap, inside what Steneck et al. (2011) defined as "gilded traps" (Fig. 4). They are social traps where collective actions, resulting from attractive economic opportunities, outweigh the concerns about social and environmental risks. In the case of Chiloé, the aquaculture industry would act as a gilded trap because its goal is to increase the economic value of natural resources, i.e., mussels and salmon, requiring a simplified ecosystem, free of predators. 


\section{DISCUSSION}

\section{The adaptive cycle and the ecosystem services}

We have described a social-ecological adaptive cycle conceptual model for Chiloé Island (southern Chile), defining its phases through a qualitative interpretation of historical documents, scientific articles, face-to-face interviews (Appendices 1 and 2), and based on the drivers that other authors have associated with each phase (Table 2). We have also used the information to analyze ecosystem services (ES) in each phase and their changes through time (Table 3 and Fig. 3) with the goal of testing if they agree with the relationships proposed in the literature (Table 1). Results show that Chiloé Island's adaptive cycle has gone through two collapse phases $\Omega$ ), the first between 1960 and 1966 and the second, validated by interviews with local social actors, between 2007 and, at least, 2016 (Fig. 2). Folke (2006:260), discussing the definition of resilience for social-ecological systems (SES), states that one of its meanings is "the degree to which the system can build and increase the capacity for learning and adaptation." However, Fath et al. (2015) emphasize the system's capacity to move through all the adaptive cycle phases. The information gathered shows that Chiloé went through the first collapse phase, moving into a reorganization phase ( $\alpha$ (i); Fig. 2), with profound changes in its social-ecological conditions. It is still too early to know the result of the second, current, collapse phase. Therefore, our historical analysis suggests that Chiloé's social-ecological system is resilient and that a new reorganization phase could rise in the following years. However, chilotes have paid the price, losing their identity, as shown in the decreasing trend of cultural ecosystem services (Fig. 3B). Alternatively, the Chiloé Island SES may be inside the rigidity trap generated by the upper (Chilean national-regional) adaptive cycle. In this case, the system could become maladaptive, losing its adaptive capabilities (Holling 2001).

Sheppard (1995) and Humpries and Winemiller (2009) mention that, when developing regional policies and programs, it is frequent to make mistakes if the adaptive history of complex systems, such as Chiloé Island, is unknown. Each generation accepts as a baseline for ecosystems and societies the conditions they knew at the beginning of their life, using them to assess changes. Soga and Gaston (2018) state that human perception is limited, and as a result, the lack of experiences, memory, or knowledge of local people about past conditions (known as "environmental generational amnesia") may generate nonsustainable objectives for socioeconomic development. Delgado et al. (2009) also propose that under uncertain conditions, a sense of "environmental nostalgia" in tune with the Spanish expression todo tiempo pasado fue mejor (the good old days) may prevail. Even considered a heuristic (e.g., Thanh et al. 2020), the adaptive cycle is a robust conceptual framework that depicts long-term changes in a SES becoming a system's environmental memory. Resulting models can then be used, along with other shorter time frameworks such as the Drivers-Pressures-State-Impact (DPSIR; Pinter et al. 2008), to improve the knowledge of the relationships between social and ecological subsystems at different time scales.

The ES analysis showed that only provisioning services agree (Fig. 3A) with the proposed hypothetical relationships with the adaptive cycle phases. This method forces researchers to gather vast amounts of information, but it allowed us to understand the long-term changes (in this case, 190 years: 1826-2016) of an SES. This long-term perspective showed that some large-scale socioeconomic processes, such as the globalization and neoliberal economy, imprinted on Chiloé social-ecological system after 1969 (Fig. 4), may have disentangled the local relationships between adaptive cycles phases and ecosystem services, as proposed (Table 1), especially for cultural ecosystem services that depend on preserving traditions (Quiñones 2020). However, Burkhard et al. (2011) state that two phases (exploitation [r] and conservation [K]) may have high uncertainties on ecosystem services, and Delgado et al. (2019a) propose ES are unpredictable in the reorganization phase $(\alpha)$. Schmitz (2010:258), discussing ecosystem complexity, proposes that we should always consider the issue of contingency, which "arises when the nature and strength of ecosystem functioning in different locations are different realizations of the same underlying process." Therefore, there are two possible explanations for our phases/services results: (1) long-term processes, i.e., cross-scale interactions, change the expected local relationships; or (2) the relationships are contingent to the type of service and the structure and functions of each ecosystem, without a general rule. We leave these two ideas as working hypotheses that should be analyzed with a broader set of empirical phases/services studies.

\section{Obstacles and traps: the potential effects of cross-scale interactions}

Cross-scale process analyses allowed us to identify the system's connections that have modified its social-ecological behavior (Fig. 4). Human well-being depends on a social-ecological systems' resilience, making the analysis of adaptive cycles and their crossscale connections necessary (McGinnis and Ostrom 2014, Fath et al. 2015). Cross-scale interactions that jump one cycle of the panarchy may be especially important to analyze, e.g., the remember connection between the global and local scale cycles (Fig. 4).

Also, looking for rigidity traps is essential to scrutinize phase changes and resilience. In our case, rigidity appeared as gilded traps (Fig. 4). Although from an economic perspective, aquaculture is attractive, it also generates risks that have been associated with gilded traps, such as a propensity to diseases (Murray and Peeler 2005), in our case, the ISA virus triggering the 2007 collapse phase ( $\Omega$; Fig. 2 and Appendix 1).

Currently, there are no local adaptive management schemes for Chiloé Island. Therefore, it is difficult to respond to global processes, e.g., the Chile-Japan agreement. Our results suggest that Chiloe Island is either in a collapse phase $(\Omega)$ or a late-stage conservation phase $(\mathrm{K})$. If the phase is the latter, we propose that the system is within a rigidity trap due to several governmental economic subsidies, or "perverse subsidies" (Bagstad et al. 2007). Vang Rasmussen and Reenberg (2012) propose that excessive subsidies may move a system into a rigidity trap because connectivity is increased through political interventions. In consequence, this type of governmental help becomes a long-term enemy of local sustainability.

Maintaining a conservation phase (K) may be a good thing for social-ecological systems, but not through rigidity traps (Fath et al. 2015). If the Chiloé adaptive cycle is in a late-stage conservation phase $(\mathrm{K})$, it will need economic diversification, a return to traditional practices, local regulations and inspections, and 
participative governance to avoid entering into a new collapse phase $(\Omega)$. However, from the perspective of public policies, Chile and other Latin American nations are centralized countries lacking the required regional-local contextualized instruments and with low social participation (Delgado et al. 2019c).

In summary, Chiloé Island's social-ecological system seems to be crossing a critical moment. It is either in a late-stage conservation phase $(\mathrm{K})$ or already in collapse $(\Omega)$. Its traditional culture has been disintegrated by external, global pressures. Two out of three ecosystem services show a long-term deterioration, independent of the phase of the cycle. Although some authors propose that it could also be an opportunity to reinvent its cultural identity (Mansilla Torres 2006), such a proposal will require an institutional-jurisdictional openness to start a bottom-up reorganization phase $(\alpha)$.

\section{CONCLUSIONS}

Based on the developed adaptive cycle model, we propose that Chiloé Island, studied as a social-ecological system, is currently going through a local collapse phase $(\Omega)$, with a socioeconomic and ecological breakdown resulting from the productive activities developed in the coastal zone, a lack of local control, and perverse subsidies. The national cycle (institutional-jurisdictional) is confined in a rigidity trap. Finally, the historical analysis of ecosystem services shows that phases/services relationships may be contextual to each service type, depending on long-term socialecological trends and cross-scale interactions.

${ }^{[1]}$ https://en.wikipedia.org/wiki/2020_Chilean_national_plebiscite

Responses to this article can be read online at: https://www.ecologyandsociety.org/issues/responses. $\mathrm{php} / 11977$

\section{Acknowledgments:}

This work was financed by CONICYT-Chile (Proyecto Fondecyt Regular $\left.N^{o} 1170532\right)$. We thank Brian Chaffin and two reviewers for their comments that helped us improve our article. We also thank the graphic artist Elizabeth Silva Saldaña for her work with images of the phases. Finally, we want to express our deep appreciation for the warm welcome from chilotes that made our work very pleasant.

\section{Data Availability:}

The data will be available upon request to the first author.

\section{LITERATURE CITED}

Abel, N., D. H. M. Cumming, and J. M. Anderies. 2006. Collapse and reorganization in social-ecological systems: questions, some ideas, and policy implications. Ecology and Society 11(1):17. https://doi.org/10.1007/s10021-013-9744-2

Allen, C. R., D. G. Angeler, A. S. Garmestni, L. H. Gunderson, and C. S. Holling. 2014. Panarchy: theory and application. Ecosystems 17:578-589. https://doi.org/10.5751/ES-01593-110117
Álvarez, R. 2011. Prácticas rituales asociadas a tierra y mar: quepucas y treputo. III Seminario "Chiloé: historia del contacto." Dirección de bibliotecas, archivos y museos, Santiago, Chile. [online] URL: http://www.patrimoniocultural.gob.cl/Recursos/ Contenidos/De $\% 20$ Ancud/archivos/PR $\%$ c 3\%81CTICAS $\%$ 20RITUALES $\% 20$ ASOCIADAS $\% 20 \mathrm{~A} \% 20$ TIERRA $\% 20 \mathrm{Y} \% 20$ MAR. pdf

Álvarez, R., D. Munita, J. Fredes, and R. Mera. 2008. La utilización de corrales de pesca en las fuentes históricas y recientes. Pages 143-170 in R. Álvarez, D. Munita, J. Fredes, and R. Mera, editors. Corrales de pesca en Chiloé. Imprenta América, Valdivia, Chile. [online] URL: http://www.bibliotecanacionaldigital.gob. cl/bnd/645/w3-article-585024.html

Angeler, D. G., S. Drakare, and R. K. Johnson. 2011. Revealing the organization of complex adaptive systems through multivariate time series modeling. Ecology and Society 16(3):5. https://doi.org/10.5751/ES-04175-160305

Amtmann, C. A., and G. Blanco. 2001. Efectos de la salmonicultura en las economías campesinas de la Región de Los Lagos, Chile. Revista Austral de Ciencias Sociales 5:93-106. [online] URL:https://www.redalyc.org/pdf/459/45900509.pdf https:// doi.org/10.4206/rev.austral.cienc.soc.2001.n5-09

Auad, G., J. Blythe, K. Coffman, and B. D. Fath. 2018. A dynamic management framework for socio-ecological system stewardship: a case study for the United States Bureau of Ocean Energy Management. Journal of Environmental Management 225:32-45. https://doi.org/10.31230/osf.io/nurca

Bagstad, K. J., K. Stapleton, and J. R. D'Agostino. 2007. Taxes, subsidies, and insurance as drivers of United States coastal development. Ecological Economics 63(2-3):285-298. https://doi. org/10.1016/j.ecolecon.2006.09.019

Baral, N., M. J. Stern, and J. T. Heinen. 2010. Growth, collapse, and reorganization of the Annapurna Conservation Area, Nepal: an analysis of institutional resilience. Ecology and Society 15 (3):10. https://doi.org/10.5751/es-03534-150310

Barrionuevo, A. 2011. Norwegians concede a role in Chilean salmon virus. The New York Times, 27 July. [online] URL: https:// www.nytimes.com/2011/07/28/world/americas/28chile.html

Barton, J., R. Pozo, Á. Román, and A. Salazar. 2013. Reestructuración urbana de un territorio glocalizado: una caracterización del crecimiento orgánico en las ciudades de Chiloé, 1979-2008. Revista de Geografía Norte Grande 56:121-142. http://dx.doi.org/10.4067/S0718-34022013000300007

Barton, J. R., and Á. Román. 2016. Sustainable development? Salmon aquaculture and late modernity in the archipelago of Chiloé, Chile. Island Studies Journal 11(2):651-672. [online] URL: https://www.islandstudies.ca/sites/islandstudies.ca/files/ISJ-11-2MS369-Barton+Roman.pdf

Beier, C., A. L. Lovecraft, and T. Chapin. 2009. Growth and collapse of a resource system: an adaptive cycle of change in public lands governance and forest management in Alaska. Ecology and Society 14(2):5. https://doi.org/10.5751/ES-02955-140205

Berkes, F., and C. Folke. 1998. Linking social and ecological systems: management practices and social mechanisms for building 
resilience. Cambridge University Press, New York, New York, USA.

Biggs, R., M. Schlüter, D. Biggs, E. L. Bohensky, S. BurnSilver, G. Cundill, V. Dakos, T. M. Daw, L. S. Evans, K. Kotschy, et al. 2012. Toward principles for enhancing the resilience of ecosystem services. Annual Review of Environment and Resources 37:421-448. https://doi.org/10.1146/annurev-environ-051211-123836

Binder, C. R., J. Hinkel, P. W. G. Bots, and C. Pahl-Wostl. 2013. Comparison of frameworks for analyzing social-ecological systems. Ecology and Society 18(4):26. http://dx.doi.org/10.5751/ ES-05551-180426

Bohensky, E. L. 2008. Discovering resilient pathways for South African water management: two frameworks for a vision. Ecology and Society 13(1):19. https://doi.org/10.5751/ES-02301-130119

Burkhard, B., B. D. Fath, and F. Müller. 2011. Adapting the adaptive cycle: hypotheses on the development of ecosystem properties and services. Ecological Modelling 222(16):2878-2890. https://doi.org/10.1016/j.ecolmodel.2011.05.016

Bustos, B., and Á. Román. 2019. A sea uprooted: islandness and political identity on Chiloé Island, Chile. Island Studies Journal 14(2):97-114. https://doi.org/10.24043/isj.91

Cabello, P., R. Torres, and C. Mellado. 2018. Conflicto socioambiental y contienda política: encuadres de la crisis ambiental de la marea roja en Chiloé(Chile). América Latina Hoy 79:59-79. https://doi.org/10.14201/alh2018795979

Capriroli, F. 2019. Desarrollo de un modelo conceptual socioecológico de los cambios de uso de suelo de la Isla Grande de Chiloé en las últimas dos décadas. Thesis. Facultad de Ciencias Agronómicas, Universidad de Chile, Santiago, Chile.

Carreiro, M. M., and W. C. Zipperer. 2011. Co-adapting societal and ecological interactions following large disturbances in urban park woodlands. Austral Ecology 36:904-915. https://doi. org/10.1111/j.1442-9993.2010.02237.x

Chaffin, B. C., A. S. Garmestani, L. H. Gunderson, M. H. Benson, D. G. Angeler, C. A. (T.) Arnold, B. Cosens, R. K. Craig, J. B. Ruhl, and C. R. Allen. 2016. Transformative environmental governance. Annual Review of Environment and Resources 41:399-423. https://doi.org/10.1146/annurev-environ-110615-085817

Delgado, L. E., and V. H. Marín. 2019. Social-ecological systems of Latin America: complexities and challenges. Springer, Cham, Switzerland. https://doi.org/10.1007/978-3-030-28452-7

Delgado L. E., V. H. Marín, R. Asún, C. Zúñiga, C. Natenzon, R. Castro-Díaz, L. D. Paredes, and F. Capriroli. 2019c. Environmental governance for the coastal marine ecosystem services of Chiloé Island (Southern Chile). Pages 389-405 in L. E. Delgado and V. H. Marín, editors. Social-ecological systems of Latin America: complexities and challenges. Springer, Cham, Switzerland. https://doi.org/10.1007/978-3-030-28452-7_21

Delgado, L. E., V. H. Marín, P. L. Bachmann, and M. TorresGomez. 2009. Conceptual models for ecosystem management through the participation of local social actors: the Río Cruces wetland conflict. Ecology and Society 14(1):50. https://doi. org/10.5751/ES-02874-140150
Delgado, L. E., D. C. Pérez-Orellana, and V. H. Marín. 2019a. Simplifying the complexity of social-ecological systems with conceptual models. Pages 15-32 in L. E. Delgado and V. H. Marín, editors. Social-ecological systems of Latin America: complexities and challenges. Springer, Cham, Switzerland. https://doi. org/10.1007/978-3-030-28452-7_2

Delgado, L. E., A. Tironi-Silva, and V. H. Marín. 2019b. Sistemas socioecológicos y servicios ecosistémicos: modelos conceptuales para el Humedal del Río Cruces (Valdivia, Chile). Pages 177-205 in C. Cerda, E. Silva-Rodríguez, and C. Briceño, editors. Naturaleza en sociedad. Una mirada a la dimensión humana de la conservación de la biodiversidad. Ocholibros Editores SpA, Santiago, Chile.

Dick, J. M., R. I. Smith, and E. M. Scott. 2011. Ecosystem services and associated concepts. Environmetrics 22(5):598-607. https:// doi.org/10.1002/env.1085

Elliff, C. I., and R. K. P. Kikuchi. 2015. The ecosystem service approach and its application as a tool for integrated coastal management. Natureza \& Conservação 13:105-111. http://dx.doi. org/10.1016/j.ncon.2015.10.001

Fath, B. D., C. A. Dean, and H. Katzmair. 2015. Navigating the adaptive cycle: an approach to managing the resilience of social systems. Ecology and Society 20(2):24. http://dx.doi.org/10.5751/ ES-07467-200224

Fath, B. D., S. E. Jørgensen, B. C. Patten, and M. Straškraba, 2004. Ecosystem growth and development. Biosystems 77 (1-3):213-228. https://doi.org/10.1016/j.biosystems.2004.06.001

Folke, C. 2006. Resilience: the emergence of a perspective for social-ecological systems analyses. Global Environmental Change 16(3):253-267. https://doi.org/10.1016/j.gloenvcha.2006.04.002

Gunderson, L. H., and C. S. Holling. 2002. Panarchy: understanding transformations in human and natural systems. Island, Washington D.C., USA.

Haider, L. J., W. J. Boonstra, G. D. Peterson, and M. Schlüter. 2018. Traps and sustainable development in rural areas: a review. World Development 101:311-321. https://doi.org/10.1016/j. worlddev.2017.05.038

Haines-Young, R., and M. Potschin. 2010. The links between biodiversity, ecosystem services and human well-being. Page 110-139 in D. Raffaelli and C. Frid, editors. Ecosystem ecology: a new synthesis. Cambridge University Press, Cambridge, UK. https://doi.org/10.1017/CBO9780511750458.007

Haines-Young, R., and M. B. Potschin. 2018. Common international classification of ecosystem services (CICES) V5.1 and guidance on the application of the revised structure. European Environment Agency, Copenhagen, Denmark. [online] URL: https://cices.eu/

Holdschlag, A., and B. M. Ratter. 2016. Caribbean island states in a social-ecological panarchy? Complexity theory, adaptability and environmental knowledge systems. Anthropocene 13:80-93. https://doi.org/10.1016/j.ancene.2016.03.002

Holling, C. S. 1986. The resilience of terrestrial ecosystems; local surprise and global change. Pages 292-317 in W. C. Clark and R. E. Munn, editors. Sustainable development of the biosphere. Cambridge University Press, Cambridge, UK. 
Holling, C. S. 1987. Simplifying the complex: the paradigms of ecological function and structure. European Journal of Operational Research 30(2):139-146. https://doi.org/10.1016/0377-2217 (87)90091-9

Holling, C. S. 2001. Understanding the complexity of economic, ecological, and social systems. Ecosystems 4:390-405. https://doi. org/10.1007/s10021-001-0101-5

Holling, C. S., and L. H. Gunderson. 2002. Resilience and adaptive cycles. Pages 25-62 in L. H. Gunderson and C. S. Holling, editors. Panarchy: understanding transformations in human and natural systems. Island, Washington, D.C., USA.

Hull, V., and J. Liu. 2018. Telecoupling: a new frontier for global sustainability. Ecology and Society 23(4):41. https://doi. org/10.5751/ES-10494-230441

Humphries, P., and K. O. Winemiller. 2009. Historical impacts on river fauna, shifting baselines, and challenges for restoration. BioScience 59(8):673-684. https://doi.org/10.1525/bio.2009.59.8.9

Instituto Nacional de Estadísticas (INE). 2017. XIX Censo Nacional de Población, Chile. Instituto Nacional de Estadísticas, Santiago, Chile. [online] URL: http://www.censo2017.cl/ descargue-aqui-resultados-de-comunas/

Joseph, J., and J. A. McGregor. 2020. Resilience. Pages 39-70 in J. Joseph and A. McGregor, editors. Wellbeing, resilience and sustainability: the new trinity of governance. Palgrave Pivot, Cham, Switzerland. https://doi.org/10.1007/978-3-030-32307-3 3

Laterra, P., P. Barral, A. Carmona, and L. Nahuelhual. 2016. Focusing conservation efforts on ecosystem service supply may increase vulnerability of socio-ecological systems. PLOS ONE 11 (5):e0155019. https://doi.org/10.1371/journal.pone.0155019

León-Muñoz, J., M. A. Urbina, R. Garreaud, and J. L. Iriarte. 2018. Hydroclimatic conditions trigger record harmful algal bloom in western Patagonia (summer 2016). Scientific Reports 8:1330. https://doi.org/10.1038/s41598-018-19461-4

Mansilla Torres, S. 2006. Dilemmas of cultural identity in a Chiloe faced with the Chilean neoliberal model. Alpha (Osorno) 23:9-36. http://dx.doi.org/10.4067/S0718-22012006000200002

Mascareño, A., R. Cordero, G. Azócar, M. Billi, P. A. Henríquez, and G. A. Ruz. 2018. Controversies in social-ecological systems: lessons from a major red tide crisis on Chiloe Island, Chile. Ecology and Society 23(4):15. https://doi.org/10.5751/ES-10300-230415

McGinnis, M. D., and E. Ostrom. 2014. Social-ecological system framework: initial changes and continuing challenges. Ecology and Society 19(2):30. http://dx.doi.org/10.5751/ES-06387-190230

Mhango, J., and J. Dick. 2011. Analysis of fertilizer subsidy programs and ecosystem services in Malawi. Renewable Agriculture and Food Systems 26(3):200-207. [online] URL: https://www.jstor.org/stable/44490653?seq=1 https://doi.org/10.1017/ $\underline{\mathrm{S} 1742170510000517}$

Motesharrei, S., J. Rivas, and E. Kalnay. 2014. Human and nature dynamics (HANDY): modeling inequality and use of resources in the collapse or sustainability of societies. Ecological Economics 101:90-102. https://doi.org/10.1016/j.ecolecon.2014.02.014
Murray, A. G., and E. J. Peeler. 2005. A framework for understanding the potential for emerging diseases in aquaculture. Preventive Veterinary Medicine 67:223-235. https://doi.org/10.1016/ j.prevetmed.2004.10.012

Nahuelhual, L., G. Saavedra, C. Jullian, M. A. Mellado, and F. Benra. 2019. Exploring traps in forest and marine socio-ecological systems of Southern and Austral Chile. Pages 323-345 in L. E. Delgado and V. H. Marín, editors. Social-ecological systems of Latin America: complexities and challenges. Springer, Cham, Switzerland. https://doi.org/10.1007/978-3-030-28452-7 18

Nayak, P. K., L. E. Oliveira, and F. Berkes. 2014. Resource degradation, marginalization, and poverty in small-scale fisheries: threats to social-ecological resilience in India and Brazil. Ecology and Society 19(2):73. http://dx.doi.org/10.5751/ ES-06656-190273

Paredes, D. 2019. Desarrollo de un modelo conceptual para el manejo de servicios ecosistémicos costeros: Isla Grande de Chiloé. Thesis. Universidad de Chile, Santiago, Chile. [online] URL: http://mgpa.forestaluchile.cl/Tesis/Paredes\%20Lorenna.pdf

Pavez, C. 2015. Salmonicultura y nuevos pescadores: relaciones de cooperación y conflicto. Pages 181-206 in Á. Román, J. R. Barton, B. Bustos, and A. Salazar, editors. Revolución salmonera: paradojas y transformaciones territoriales en Chiloé. Instituto de Estudios Urbanos y Territoriales UC, RIL Editores, Santiago, Chile.

Pereira, L. M., T. Karpouzoglou, N. Frantzeskaki, and P. Olsson. 2018. Designing transformative spaces for sustainability in socialecological systems. Ecology and Society 23(4):32. https://doi. org/10.5751/ES-10607-230432

Pintér, L., D. Swanson, I. Abdel-Jelil, K. Nagatani-Yoshida, A. Rahman, and M. Kok. 2008. IEA Training manual: a training manual on integrated environmental assessment and reporting. Training module 5: integrated analysis of environmental trends and policies. United Nations Environment Programme, International Institute for Sustainable Development, Winnipeg, Manitoba, Canada. [online] URL: https://wedocs.unep.org/bitstream/ handle $/ 20.500 .11822 / 11306 /$ module-5.pdf?sequence $=1 \& a m p \%$

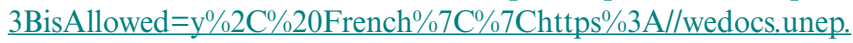
org/bitstream/ha

Quiñones, D. 2020. Modelos conceptuales del uso de los servicios ecosistémicos de la cuenca de Yaldad, Quellón (Isla Grande de Chiloé). Undergraduate Thesis. Facultad de Ciencias. Universidad de Chile, Santiago, Chile.

Schmitz, O. J. 2010. Resolving ecosystem complexity. Princeton University Press, Princeton, New Jersey, USA.

Sheppard, C. 1995. The shifting baseline syndrome. Marine Pollution Bulletin 30(12):766-767. https://doi.org/10.1016/0025-326X (95)90079-Q

Soga, M., and K. J. Gaston. 2018. Shifting baseline syndrome: causes, consequences, and implications. Frontiers in Ecology and the Environment 16(4):222-230. https://doi.org/10.1002/fee.1794

Steneck, R. S., T. P. Hughes, J. E. Cinner, W. N. Adger, S. N. Arnold, F. Berkes, S. A. Boudreau, K. Brown, C. Folke, L. Gunderson, et al. 2011. Creation of a gilded trap by the high 
economic value of the Maine lobster fishery. Conservation Biology 25(5):904-912.

Tenza, A., I. Pérez, J. Martínez-Fernández, and A. Giménez. 2017. Understanding the decline and resilience loss of a long-lived social-ecological system: insights from system dynamics. Ecology and Society 22(2):15. https://doi.org/10.5751/ES-09176-220215

Thanh, H. T., P. Tschakert, and M. R. Hipsey. 2020. Tracing environmental and livelihood dynamics in a tropical coastal lagoon through the lens of multiple adaptive cycles. Ecology and Society 25(1):31. https://doi.org/10.5751/ES-11489-250131

UN Department of Economic and Social Affairs. 2020. World economic situation and prospects (WESP) report. UN Department of Economic and Social Affairs, New York, New York, USA. [online] URL: https://www.un.org/development/ desa/dpad/document gem/global-economic-monitoring-unit/worldeconomic-situation-and-prospects-wesp-report/

Vang Rasmussen, L., and A. Reenberg. 2012. Collapse and recovery in Sahelian agro-pastoral systems: rethinking trajectories of change. Ecology and Society 17(1):14. http://dx. doi.org/10.5751/ES-04614-170114

Vargas, D. 2016. Reflexiones en torno al mayo chilote. Le Monde Diplomatique, 2 August. [online] URL: https://www.lemondediplomatique. cl/Reflexiones-en-torno-al-mayo.html

Walker, B., S. Carpenter, J. Anderies, N. Abel, G. S. Cumming, M. Janssen, L. Lebel, J. Norberg, G. D. Peterson, and R. Pritchard. 2002. Resilience management in social-ecological systems: a working hypothesis for a participatory approach. Conservation Ecology 6(1):14. https://doi.org/10.5751/ES-00356-060114

Walker, B. H., L. H. Gunderson, A. P. Kinzig, C. Folke, S. R. Carpenter, and L. Schultz. 2006. A handful of heuristics and some propositions for understanding resilience in social-ecological systems. Ecology and Society 11(1):13. https://doi.org/10.5751/ ES-01530-110113

Williams, A., G. Whiteman, and S. Kennedy. 2019. Cross-scale systemic resilience: implications for organization studies. Business and Society. https://doi.org/10.1177/0007650319825870

Winkel, T., P. Bommel, M. Chevarría-Lazo, G. Cortes, C. Del Castillo, P. Gasselin, F. Léger, J. P. Nina-Laura, S. Rambal, M. Tichit, J. F. Tourrand, J. J. Vacher, A. Vassas-Toral, M. VieiraPak, and R. Joffre. 2016. Panarchy of an indigenous agroecosystem in the globalized market: the quinoa production in the Bolivian Altiplano. Global Environmental Change 39:195-204. https://doi.org/10.1016/j.gloenvcha.2016.05.007

Zhang, J., T. Connor, H. Yang, Z. Ouyang, S. Li, and J. Liu. 2018. Complex effects of natural disasters on protected areas through altering telecouplings. Ecology and Society 23(3):17. https://doi. org/10.5751/ES-10238-230317 


\section{Appendix 1}

Capitals of the historical phases of Chiloé local (social-ecological) adaptive cycle. References are cited at the end of this appendix

Capitals of Phase r (1): (1826 - 1959)

\begin{tabular}{|c|c|c|}
\hline \multicolumn{3}{|c|}{ Ecological Subsystem } \\
\hline \multirow{5}{*}{$\begin{array}{c}\text { Natural } \\
\text { capital }\end{array}$} & $\begin{array}{l}\text { The western coast of the archipelago, and on the coasts of the inland sea, was filled with wetlands, peatlands, } \\
\text { native forests, lakes, rivers, and reach marine ecosystems. Coastal marine ecosystems provided macroalgae, } \\
\text { crustaceans, mollusks, and fishes. Those marine resources, mixed with potatoes, were the basic food for Chilotes. } \\
\text { Other crops (wheat, oats, some legumes) and livestock were complementary. }\end{array}$ & $\begin{array}{l}\text { Cárdenas and Villagrán } \\
(2005)\end{array}$ \\
\hline & $\begin{array}{l}\text { Island forests were already suffering anthropogenic pressures due mostly to wood extraction (mostly larches) } \\
\text { both for building and as firewood, vegetation fibers, and herbs for medical purposes. There also was the change } \\
\text { from forests to prairies for agronomic purposes. }\end{array}$ & $\begin{array}{l}\text { Muñoz Carreño (2016), San } \\
\text { Carlos et al. (2018), }\end{array}$ \\
\hline & Use of natural fertilizers, marine algae, for potatoes cultures. The use of birds guano started in 1940. & $\begin{array}{l}\text { Cárdenas and Villagrán } \\
\text { (2005), Andrade (2017) }\end{array}$ \\
\hline & $\begin{array}{l}\text { There were two varieties of potatoes, both susceptible to a fungus known as "tizón" (Phytophthora infestans), a } \\
\text { disease that it is believed it arrived from Argentina, unnoticed until 1949. New colonists introduced new potatoes } \\
\text { varieties more resistant to fungi during } 1895 \text { and by } 1950 \text { they replaced native potatoes. }\end{array}$ & $\begin{array}{l}\text { Cárdenas and Villagrán } \\
\text { (2005), Andrade (2017) }\end{array}$ \\
\hline & Large bivalves' extraction between 1930 and 1940. & Sfeir (2005) \\
\hline \multicolumn{3}{|c|}{ Social Subsystem } \\
\hline \multirow{3}{*}{$\begin{array}{l}\text { Bridge social } \\
\text { capital }\end{array}$} & $\begin{array}{l}\text { Chiloé becomes isolated from its former markets after its incorporation to Chile in } 1826 \text {, due to a decrease in } \\
\text { maritime transport and isolation from the rest of the country. }\end{array}$ & San Carlos et al. (2018) \\
\hline & $\begin{array}{l}\text { The Chilean state becomes the owner of } 70 \% \text { of the island, including areas that formerly belonged to indigenous } \\
\text { communities. }\end{array}$ & Marino (1985) \\
\hline & $\begin{array}{l}\text { During 1950, the Chilean government imposed an emigration process off the island due to its alleged misery. } \\
\text { The poverty moved Chilotes away from agriculture toward the harvest of coastal marine species. }\end{array}$ & Montenegro (2016) \\
\hline \multirow{3}{*}{$\begin{array}{l}\text { Cultural } \\
\text { capital and } \\
\text { identity }\end{array}$} & Chilotes' culture was built before this phase through the syncretism of indigenous peoples and Spaniard colonists & $\begin{array}{l}\text { Cárdenas and Villagrán } \\
(2005)\end{array}$ \\
\hline & $\begin{array}{l}\text { The isolation is an important factor that explains the maintenance of Chilote's identity and culture. Two } \\
\text { mythological entities, one of the forests (El Trauco) and one of the coasts (La Pincoya), were particularly } \\
\text { important as resources regulators. Thus, "Chilotes extracted only what was necessary for their life" }\end{array}$ & $\begin{array}{l}\text { Personal communication } \\
\text { (Interviewee from } \\
\text { Dalcahue) }\end{array}$ \\
\hline & $\begin{array}{l}\text { Efficient rural self-subsistence economy. Productive activities oriented to self-consumption along with sales or } \\
\text { exchanges to benefit the family and social activities. }\end{array}$ & $\begin{array}{l}\text { Gajardo et al. (2017); } \\
\text { Montenegro (2016); } \\
\text { Daughters (2016) } \\
\end{array}$ \\
\hline \multirow[b]{2}{*}{$\begin{array}{l}\text { Economic } \\
\text { capital }\end{array}$} & $\begin{array}{l}\text { Emigration due to the lack of working opportunities due to excessive land division, general poverty, and low } \\
\text { expectations from men. }\end{array}$ & \begin{tabular}{|l|} 
Yáñez Aguilar (2011); \\
Montenegro, (2016); \\
Saldívar Arellano (2017) \\
\end{tabular} \\
\hline & $\begin{array}{l}\text { During } 1850 \text { many men migrate to work on sea wolf and/or forest exploitations abandoning agriculture and } \\
\text { leaving women and elderlies in charge of them. This process reverts at the beginning of the XX century due to a } \\
\text { decrease in forest exploitation with Chilotes returning to potatoes harvest until the middle of the century when } \\
\text { fungi start creating problems. }\end{array}$ & $\begin{array}{l}\text { Cárdenas and Villagrán } \\
\text { (2005); Saavedra Gallo } \\
\text { (2013) }\end{array}$ \\
\hline $\begin{array}{l}\text { Human } \\
\text { capital }\end{array}$ & $\begin{array}{l}\text { High family and community cohesion. Families share agricultural grounds. This custom is disturbed due to the } \\
\text { land division generated by the Chilean government. }\end{array}$ & Marino (1985) \\
\hline
\end{tabular}




\section{Capitals of Phase $\Omega(1)$ : $(1960-1966)$}

\section{Ecological Subsystem}

\begin{tabular}{|c|c|c|}
\hline \multicolumn{3}{|c|}{ Ecological Subsystem } \\
\hline \multirow{5}{*}{$\begin{array}{l}\text { Natural } \\
\text { capital }\end{array}$} & $\begin{array}{l}\text { "The earthquake of May 22nd, } 1960 \text { lasted three minutes, it was } 9.5 \mathrm{Mw} \text {. That is, it was a cataclysm. We lost } \\
\text { everything here, we lost all coastal zones, the tsunami was very strong people said goodbye in between the three } \\
\text { big waves. It was terrible, we saw gases coming from the earth, we could not eat fishes and seafood, all of them } \\
\text { were contaminated. Chiloe then opened to the world, roads were opened, motorboats arrived, and it was the end } \\
\text { of sailing boats. The positive issue was the existence of outside help, that, given the magnitude of the disaster, it } \\
\text { was very important." }\end{array}$ & $\begin{array}{l}\text { Personal communication } \\
\text { (Interviewee from } \\
\text { Dalcahue) }\end{array}$ \\
\hline & $\begin{array}{l}\text { After the earthquake, there was a closure of seafood fishing. Also, the falling of smut affected potatoes cultures } \\
\text { until 1961, further reappearing during } 1964 \text {. As a result, agricultures switch to culturing beet. During that period } \\
\text { cattle were affected by diverse pathogens. }\end{array}$ & Urbina (1996) \\
\hline & Ground-level subsidence with land flooding and the growth of wetlands made forest regeneration difficult. & Quintanilla (2004) \\
\hline & $\begin{array}{l}\text { Regional depletion of natural banks of "chorito" (Mytilus edulis) and "cholga" (Aulacomya ater). "Choro zapato" } \\
\text { (Choromytilus chorus) was to the border of extinction and there was a collapse of natural banks of Chilean oysters } \\
\text { (Ostrea chilensis) due to the null extraction up to } 1961 \text { and under } 100 \text { tones between } 1962 \text { and } 1966 .\end{array}$ & Sfeir (2005) \\
\hline & $\begin{array}{l}\text { Replacement begins of traditional, chilote, fertilizers (based on marine algae and plant leaves) by the chemical } \\
\text { super triple phosphate. }\end{array}$ & $\begin{array}{l}\text { Cárdenas and Villagrán } \\
(2005)\end{array}$ \\
\hline \multicolumn{3}{|c|}{ Social Subsystem } \\
\hline $\begin{array}{l}\text { Bridge social } \\
\text { capital }\end{array}$ & $\begin{array}{l}\text { After the earthquake, the island's human population gets temporally isolated, with few help networks and without } \\
\text { immediate communication with the continent. }\end{array}$ & Manns (1972) \\
\hline $\begin{array}{l}\text { Cultural } \\
\text { capital and } \\
\text { identity }\end{array}$ & $\begin{array}{l}\text { The construction of the Castro-Ancud route begins after the earthquake, making land transportation possible and } \\
\text { negatively affecting the traditional maritime transport. }\end{array}$ & $\begin{array}{l}\text { Mancilla and Mardones } \\
(2010)\end{array}$ \\
\hline \multirow{5}{*}{$\begin{array}{l}\text { Economic } \\
\text { capital }\end{array}$} & $\begin{array}{l}\text { Exports are profoundly affected due to the destruction of the train and docks. Employment starts depending on } \\
\text { the generation of public structures, producing serious unemployment. }\end{array}$ & Urbina (1996) \\
\hline & $\begin{array}{l}\text { Seafood and macroalgae increase their value in Chile; the beginning of the current scenario of economic } \\
\text { transformations. }\end{array}$ & Montenegro (2016) \\
\hline & $\begin{array}{l}\text { The earthquake generated the emigration of impoverished rural families from the island toward Argentina and } \\
\text { Magallanes looking for better life conditions. }\end{array}$ & Saldívar Arellano (2017) \\
\hline & The earthquake, and the following tsunami, buried the veins of gold making small scale gold-digging impossible & Gajardo et al. (2017) \\
\hline & $\begin{array}{l}\text { "The earthquake produced many changes. Here a customs benefit law is enacted (no taxes as an economic } \\
\text { incentive), that persisted between } 1960 \text { and } 1970 \text {. This "free port" allows the beginning of tourism, with outsiders } \\
\text { starting to visit the island". }\end{array}$ & $\begin{array}{l}\text { Personal communication } \\
\text { (Interviewee from Castro) }\end{array}$ \\
\hline $\begin{array}{l}\text { Union social } \\
\text { capital }\end{array}$ & $\begin{array}{l}\text { "The earthquake generates a reorganization of Chiloe's community. The country asks the catholic church to } \\
\text { send a leader that may generate hope after the catastrophe. They sent an important priest, and everybody would } \\
\text { go to Ancud to hear his prayers. This generated peace but people were still fighting for the food arriving from } \\
\text { the continent. There also were connectivity changes, road building, and suddenly houses stop looking at the sea }\end{array}$ & $\begin{array}{l}\text { Personal communication } \\
\text { (Interviewee from } \\
\text { Dalcahue) }\end{array}$ \\
\hline
\end{tabular}




\begin{tabular}{|l|l|l|}
\hline $\begin{array}{l}\text { (Chiloé's tradition) and start looking at the road. Fishing pens also disappear due to the modification of the } \\
\text { coastline". }\end{array}$ & \\
\hline
\end{tabular}

\section{Capitals of Phase $\alpha$ : $(1967$ - 1973)}

\section{Ecological Subsystem}

\begin{tabular}{|c|c|c|}
\hline \multicolumn{3}{|c|}{ Ecological Subsystem } \\
\hline \multirow{4}{*}{$\begin{array}{l}\text { Natural } \\
\text { capital }\end{array}$} & There is indiscriminate cutting of native forests for the export of raw materials to Asia. & $\begin{array}{l}\text { Sepúlveda and Geisse } \\
\text { (1995) }\end{array}$ \\
\hline & $\begin{array}{l}\text { The export of chips from industrial waste pulp for cellulose begins. Also, the high demand for short fiber chips } \\
\text { leads to the use of the best native wood for chips. }\end{array}$ & \begin{tabular}{|l|} 
Hormazábal Henríquez \\
$(2006)$
\end{tabular} \\
\hline & $\begin{array}{l}\text { Development of mussel farming on rafts with governmental funds (1967). Seed collection of "cholga" } \\
\text { (Aulacomya ater) starts. }\end{array}$ & GESAM (2006) \\
\hline & $\begin{array}{l}\text { "Up until 1970, you could still have natural banks of seafood. Chilotes would extract from nature only that } \\
\text { necessary for its maintenance, not for sale. Fishing pens are one example of this." }\end{array}$ & $\begin{array}{l}\text { Personal communication } \\
\text { (Interviewee from } \\
\text { Dalcahue) }\end{array}$ \\
\hline \multicolumn{3}{|c|}{ Social Subsystem } \\
\hline \multirow{4}{*}{$\begin{array}{l}\text { Bridge social } \\
\text { capital }\end{array}$} & $\begin{array}{l}\text { The almost disappearance of mussel's banks after the earthquake motivated the Chilean state to start a research } \\
\text { program to develop cultures. So, culture centers were established in several locations. At the end of the 70's } \\
\text { decade, they are transferred to other institutions and universities and later to private enterprises. }\end{array}$ & Sfeir (2005) \\
\hline & The Chilean state, in 1967, encourages the economic development, mostly of mussels farming. & $\begin{array}{l}\text { "El gran auge de los } \\
\text { choritos en Chiloé" (2007) }\end{array}$ \\
\hline & $\begin{array}{l}\text { The agriculture reform law }\left(\mathrm{N}^{\circ} 16.640\right) \text { enters into force in } 1967 . \text { Its main goal is to modern social relations } \\
\text { through land redistributions, generation of cooperatives and peasant's unions. }\end{array}$ & Altieri and Rojas (1999) \\
\hline & Beginning of the introduction of Pacific salmon (Chile-Japan agreement, 1969). & $\begin{array}{l}\text { Amtmann and Blanco } \\
\text { (2001) }\end{array}$ \\
\hline $\begin{array}{l}\text { Cultural } \\
\text { capital and } \\
\text { identity }\end{array}$ & $\begin{array}{l}\text { The local ancestral practice of the collective fishing pens is intrinsically attached to the local belief system and } \\
\text { allows the maintenance of community access to marine spaces and extraction of species in low-scale capture. }\end{array}$ & Álvarez et al. (2008) \\
\hline \multirow{4}{*}{$\begin{array}{l}\text { Economic } \\
\text { capital }\end{array}$} & $\begin{array}{l}\text { Diversification of economic activities and system's reorganization. Gold veins reappear in 1965, and dairy } \\
\text { product's cooperatives (CHILOLAC) start in } 1969 \text {. }\end{array}$ & $\begin{array}{l}\text { Salières et al. (2005), } \\
\text { Gajardo et al. (2017) }\end{array}$ \\
\hline & Handicraft's market growth to sustain the beginning of tourism in the island. & $\begin{array}{l}\text { Cárdenas and Villagrán } \\
(2005)\end{array}$ \\
\hline & $\begin{array}{l}\text { There is a diversification of the economy matrix, influencing social and economic relationships in the } \\
\text { archipelago. }\end{array}$ & Mansilla Torres (2006) \\
\hline & The National Mining Company (ENAMI) encourages gold mining. & Gajardo et al. (2017) \\
\hline $\begin{array}{l}\text { Human } \\
\text { capital }\end{array}$ & Poverty relates to poor soil's condition, erosion, illiteracy, lack of health systems and of state presence. & Grenier (1984) \\
\hline \multirow{2}{*}{$\begin{array}{l}\text { Union social } \\
\text { capital }\end{array}$} & New associativity: cooperatives and peasant unions. & Altieri and Rojas (1999) \\
\hline & $\begin{array}{l}\text { The aquaculture industry changes barter and reciprocity in monetary relationships. The idea of mutual obligation } \\
\text { among neighbors decreases and traditional practices. }\end{array}$ & $\begin{array}{l}\text { Saliéres et al. (2005), } \\
\text { Daughters (2009) }\end{array}$ \\
\hline
\end{tabular}




\section{Capitals of Phase r (2): (1974 - 1995)}

\section{Ecological Subsystem}

Natural $\quad$ In 1974 salmon production begins with eggs imported from USA. In 1979 a Japanese-Chilean enterprise starts

capital culturing pacific salmon in the region. Later in 1984 the Pacific oyster is introduced in Chiloé coastal zone for culturing.

In 1980, free access to resources, guided by the neoliberal model, generates overexploitation, with negative social, economic, and ecological impacts. It also changed traditional fishing practices.

In 1981, the salmon aquaculture industry gets affected by Pacific salmon syndrome. In 1998 there is massive fish mortality due to the bloom of the microalgae Heterosigma akashiwo and in 1989 a bacterial disease kills many fishes. Later, in 1993, a parasite isopod appears in Chiloé salmons.

Increase in the harvest of coastal marine algal prairies during the ' $80 \mathrm{~s}$.

The National Fisheries and Aquaculture law is enforced in 1989, modified in 1991 and 1997. In 1994 appears the national policy on the use of coastal zones.

The salmon industry in Chile uses antibiotics, fungicides and algicides and encourages the fisheries of Merluccius australis (southern hake).

Four million salmons escape from their cages between 1994 and 1996, and later are used as artisan fisheries resource.

Mussel farming was a secondary activity during the ' 80 s, but it grows in the ' 90 s when it is considered one of the most important Chilean productive revolutions.

The industrial economy starts using native forest wood both for building purposes, firewood, and splinters. During the ' 80 s forest exploitation for splinters is intensified mostly from native forests.

There is a diversification in land use with governmental support, but without regulation. Forestry plantation increase $48.7 \%$ between $1989 / 90$ and $1997 / 98$.

\section{Social Subsystem}

Bridge social In 1976 the Undersecretariat for Fisheries is created and in 1978 the National Fisheries Service. Also, in 1976 capital

Chile Foundation (Fundación Chile) starts its operation based on state and international participation. Later the foundation starts salmon farming operations in Chiloé through linked enterprises.

Salmon farming ends the free access to the coastal border. The law then grants rights for the use of marine resources that become tradable rights.

An association of salmon producers (SALMONCHILE) is created in 1985 and a similar one for mussel farmers (AMICHILE) is created in 1991. Both with the idea of supporting export processes.

In 1974 a splinter production society is generated in Chiloé, to cut 125 thousand hectares of native forest. The response is the creation of a foundation (FUNDECHI) that starts reporting the consequences of the splinter project. As a result, Chiloé National Park is created in 1983 and in 1995 the park is returned to the Huilliche people.

Claude et al. (2000), Aros and Marchant (2018)

Gajardo and Ther (2011)

Fryer et al. (1990), Carvajal

and González (1990)

Sievers et al. (1996)

Sfeir (2005)

Marín and Gelcich (2012),

Alvarez et al. (2008)

López and Buschmann (1991); GESAM (2006), Coq-Huelva et al. (2018)

"El gran auge de los

choritos en Chiloé" (2007)

Cárdenas and Villagrán

(2005), Hormazába

Henríquez (2006)

Amtmann and Blanco

(2001)

Claude et al. (2000),

Fløysand and Román

(2008)

Ramírez et al. (2009)

Barton and Fløysand (2010)

Barros (1980), Oltremari

and Guerrero (2003)

Alcalde Silva (2014) 


\begin{tabular}{|c|c|c|}
\hline & Artisan fisheries is regulated through the General Fisheries and Aquaculture law (1991) near the end of this phase. & $\begin{array}{l}\text { Arenas et al. (2001), Coq- } \\
\text { Huelva et al. (2018) }\end{array}$ \\
\hline \multirow{3}{*}{$\begin{array}{l}\text { Cultural } \\
\text { capital and } \\
\text { identity }\end{array}$} & $\begin{array}{l}\text { The government modifies the fisheries and aquaculture law in 1991. The main change is the limitation for artisan } \\
\text { fishermen to work only in its region, stopping the traditional custom of Chilotes fishing in other regions. }\end{array}$ & Marín and Gelcich (2012) \\
\hline & $\begin{array}{l}\text { "The introduction of a new political and economic system, neoliberal, generates a series of changes, where } \\
\text { materialism is everything and the spiritual side is weak. Here in Chiloé, there is a destruction of natural and } \\
\text { cultural patrimony. (...)In this model the only thing important is money, my neighbor is not important nor my } \\
\text { cooperation history". }\end{array}$ & $\begin{array}{l}\text { Personal communication } \\
\text { (Interviewee from } \\
\text { Dalcahue) }\end{array}$ \\
\hline & Fishing pens ends in the 1980's decade. & Álvarez Abel (2016) \\
\hline \multirow{4}{*}{$\begin{array}{l}\text { Economic } \\
\text { capital }\end{array}$} & $\begin{array}{l}\text { In } 1984 \text { there are nine enterprises producing salmon, initiated mostly with Chilean capitals. They increase } \\
\text { employment in Chiloé, but it is precarious and with high personal risks (e.g. injuries). }\end{array}$ & $\begin{array}{l}\text { Montero (2004), Salgado } \\
\text { Reyes (2005), Aguayo and } \\
\text { Barriga (2016) }\end{array}$ \\
\hline & $\begin{array}{l}\text { The Los Lagos Region from } 1985 \text { until the end of this phase change from being a forestry-agriculture region to } \\
\text { an aquaculture zone. Agriculture, hunting, and fishing labor force decreased by } 9.8 \% \text {, while manufacture } \\
\text { decreased by } 18.1 \% \text {. }\end{array}$ & $\begin{array}{l}\text { Antmann and Blanco } \\
(2001)\end{array}$ \\
\hline & $\begin{array}{l}\text { High increase in salmon exports }(250 \% \text { in } 1987) \text { reaching } 30 \text { countries around the world. In } 1994 \text { Chile becomes } \\
\text { the second world salmon producer. }\end{array}$ & $\begin{array}{l}\text { Montero (2004), Bravo } \\
\text { Sánchez (2004), Fløysand } \\
\text { and Román (2008), } \\
\text { Ceballos et al. (2018) }\end{array}$ \\
\hline & In the year 1980, the selling of rural residential properties starts to be used for tourism. & Cereceda and Dahse (1980) \\
\hline \multirow[t]{3}{*}{$\begin{array}{c}\text { Human } \\
\text { capital }\end{array}$} & $\begin{array}{l}\text { In the '80s salmon aquaculture industries install big hatcheries, generating a demand for labor generating the } \\
\text { proletarianization of the Chiloé's peasants. }\end{array}$ & Mansilla Torres (2006) \\
\hline & $\begin{array}{l}\text { The emigration of Chilotes to Patagonia decreases, due to the new employment opportunities. This generates a } \\
\text { decrease in the labor force of rural communities. }\end{array}$ & $\begin{array}{l}\text { Barton and Román (2016), } \\
\text { Daughters (2016) }\end{array}$ \\
\hline & Immigrants from other zones of Chile start appearing in Chiloé. There is also an increase in education. & Zanlungo et al. (2015) \\
\hline \multirow[t]{2}{*}{$\begin{array}{l}\text { Union social } \\
\text { capital }\end{array}$} & $\begin{array}{l}\text { "A financial system for farmers starts, along with the arrival of enterprises. Individualism is born! Chilotes have } \\
\text { to work in the enterprises, with bad salaries and abuses. Self-maintenance is no longer possible, everything is } \\
\text { more expensive." }\end{array}$ & $\begin{array}{l}\text { Personal communication } \\
\text { (Interviewee from } \\
\text { Dalcahue) }\end{array}$ \\
\hline & $\begin{array}{l}\text { "There is a decrease in the trust after the military coup, decreasing traditional cooperative activities. There is } \\
\text { also a decrease in self-maintenance capabilities. Young people go to work for industries." }\end{array}$ & $\begin{array}{l}\text { Personal communication } \\
\text { (Interviewee from } \\
\text { Dalcahue) }\end{array}$ \\
\hline
\end{tabular}




\section{Capitals of Phase K: (1996 - 2006)}

\section{Ecological Subsystem}

\begin{tabular}{|c|c|c|}
\hline \multicolumn{3}{|c|}{ Ecological Subsystem } \\
\hline \multirow{8}{*}{$\begin{array}{l}\text { Natural } \\
\text { capital }\end{array}$} & $\begin{array}{l}\text { During } 1997 \text { salmon production grows eight times, and regional fishmeal becomes the largest in the country. } \\
\text { However, there is an increase in salmon diseases, infecting a local species. }\end{array}$ & Claude et al. (2000) \\
\hline & $\begin{array}{l}\text { There is an inverse relationship between salmon aquaculture and the population of sea wolf, (Otaria flavescens). } \\
\text { One of the causes would be intentional catches to avoid sea wolf's attacks on salmon cages. }\end{array}$ & Buschmann et al. (2002) \\
\hline & There is an increase in the frequency and spatial coverage of harmful algal blooms, reaching Chiloé in 2002. & Molinet et al. (2003) \\
\hline & There is an increase (by a factor of 7.5) in sardine and anchovy catches in the period 1999-2009. & Coq-Huelva et al. (2018) \\
\hline & The National Forestry Corporation (CONAF) approves subsidies to forest in fragile soils (“ñadis"). & Gatica (2012) \\
\hline & $\begin{array}{l}\text { During the period } 1998-2013 \text {, there is a loss of native forest of } 10268 \text { hectares, while forestry increases from } 623 \\
\text { to } 5443 \text { hectares. }\end{array}$ & Frêne et al. (2014) \\
\hline & $\begin{array}{l}\text { Pinus spp. and Eucalyptus spp. are a potentially accelerated decrease in water reserves due to young forestry } \\
\text { plantations. }\end{array}$ & Oyarzún and Huber (1999) \\
\hline & $\begin{array}{l}\text { In } 1998 \text { the export of mosses (Sphagnum spp.) and peat starts, making this an important source of income during } \\
\text { the next decade, influencing regional hydric balance. }\end{array}$ & $\begin{array}{l}\text { Díaz et al. (2005), Zegers et } \\
\text { al. (2006) }\end{array}$ \\
\hline \multicolumn{3}{|c|}{ Social Subsystem } \\
\hline \multirow{4}{*}{$\begin{array}{l}\text { Bridge social } \\
\text { capital }\end{array}$} & The National policy on aquaculture is approved during 2003. & Bermúdez (2010) \\
\hline & The government authorizes Chilotes to fish in the Aysén Region. & Marín and Gelcich (2012) \\
\hline & The government creates a buffer zone between Chiloé National Park and human settlements. & $\begin{array}{l}\text { Oltremari and Guerrero } \\
(2003)\end{array}$ \\
\hline & $\begin{array}{l}\text { Hacia el final de esta fase, en } 2004 \text { ocurre el anuncio público de intensificar los planes para construir un puente } \\
\text { que conectaría Chiloé por tierra mediante un megaproyecto de puente y posteriormente se propone el plan Chiloé } \\
\text { del MOP. }\end{array}$ & Delamaza et al. (2012) \\
\hline \multirow[t]{2}{*}{$\begin{array}{l}\text { Cultural } \\
\text { capital and } \\
\text { identity }\end{array}$} & $\begin{array}{l}\text { In } 2003 \text { the Ministry of culture (Government of Chile) was created, an important milestone, since Chiloé becomes } \\
\text { a powerful pole of tourist attraction. This from the exploitation and construction of a performative and } \\
\text { stereotypical image of a natural, magical and mythological place, anchored in a rurality that in many respects } \\
\text { seems to be pre-modern, and which, judging by the increasing tourist flow, would be meeting the needs of } \\
\text { exoticism of a visitor of urban origin who seeks difference and cultural and natural 'authenticity'. }\end{array}$ & $\begin{array}{l}\text { Mansilla Torres (2006), } \\
\text { Ulloa and Del Valle (2014) }\end{array}$ \\
\hline & $\begin{array}{l}\text { In 2000, UNESCO designated several historic churches in Chiloé (built entirely of wood from native forests) as } \\
\text { World Heritage Sites. These unique churches were built in the late } 1700 \mathrm{~s} \text { and during the } 1800 \mathrm{~s} \text {. }\end{array}$ & Ortiz et al. (2014) \\
\hline \multirow{2}{*}{$\begin{array}{l}\text { Economic } \\
\text { capital }\end{array}$} & $\begin{array}{l}\text { The Ministry of Agriculture since the beginning of this phase (1996) accentuates international exports. Chile } \\
\text { joins Southern Common Market (MERCOSUR). However, regional industries start showing economic crises. }\end{array}$ & $\begin{array}{l}\text { Torres (2000), Antmann } \\
\text { and Blanco (2001) }\end{array}$ \\
\hline & $\begin{array}{l}\text { During } 1997 \text { the US Chamber of Commerce accuses Chilean producers of dumping, occurring in parallel to the } \\
\text { Asian crisis affecting salmon prices.However, despite this, there is no noticeable effect on the industry, but rather } \\
\text { its consolidation with the start of the process of company acquisitions and mergers, together with an aggressive }\end{array}$ & $\begin{array}{l}\text { Antmann and Blanco } \\
\text { (2001), Barton and } \\
\text { Fløysand (2010) }\end{array}$ \\
\hline
\end{tabular}




\begin{tabular}{|c|c|c|}
\hline & $\begin{array}{l}\text { transnational expansion in the industry in } 1999 \text {. The agricultural census (1997) shows that family forest } \\
\text { exploitation is only } 1 \% \text { of total forestry production. }\end{array}$ & \\
\hline & In the first years of the 2000-decade salmon farming starts emigrating from Chiloé. & Estay and Chávez (2015) \\
\hline & People increase their purchasing power as a result of the development of the salmon industry. & Barrett et al. (2002) \\
\hline & Salmon farming modifies the traditional potatoes market, resulting in a relocation of this activity outside Chiloé. & $\begin{array}{l}\text { Cárdenas and Villagrán } \\
(2005)\end{array}$ \\
\hline $\begin{array}{c}\text { Human } \\
\text { capital }\end{array}$ & $\begin{array}{l}\text { The automation of processes in the salmon industry at the end of the ' } 90 \text { s generates a } 40 \% \text { decrease in } \\
\text { employment. }\end{array}$ & Claude et al. (2000) \\
\hline \multirow[b]{2}{*}{$\begin{array}{l}\text { Union social } \\
\text { capital }\end{array}$} & $\begin{array}{l}\text { Near the end of the } 2000 \text {-decade NGOs encourage the creation of labor unions (TERRAM, Ecoocéanos, among } \\
\text { others.), reaching } 50 \% \text { of all island workers. }\end{array}$ & $\begin{array}{l}\text { Ramírez et al. (2010), } \\
\text { Oseland et al. (2012) }\end{array}$ \\
\hline & $\begin{array}{l}\text { In 2002, the salmon sector signed the Clean Production Agreement of the National Council for Clean Production, } \\
\text { dependent on the Ministry of economy (Government of Chile), and in 2003, a "Code of Good Practice" was } \\
\text { developed by SALMONCHILE. }\end{array}$ & Muñoz (2006) \\
\hline
\end{tabular}




\section{Capitals of Phase $\Omega(2)$ : (2007 - 2016)}

\begin{tabular}{|c|c|c|}
\hline \multicolumn{3}{|c|}{ Ecological Subsystem } \\
\hline \multirow{7}{*}{$\begin{array}{l}\text { Natural } \\
\text { capital }\end{array}$} & The beginning of this phase (2007) is marked by the ISA virus crisis, making salmons unmarketable. & Bustos (2015) \\
\hline & Increase in harmful algal blooms. & Sandoval et al. (2018) \\
\hline & $\begin{array}{l}\text { During } 2013 \text { Chile becomes the second world producer of mussels, exporting } 240 \text { thousand tones, and obtaining } \\
99 \% \text { from natural produced larvae. So, natural mussel banks show low recruitment. }\end{array}$ & $\begin{array}{l}\text { Avendaño et al. (2011), } \\
\text { FAO (2015); Molinet et al. } \\
\text { (2017) }\end{array}$ \\
\hline & $\begin{array}{l}\text { During February } 2016 \text { a massive algal bloom of Pseudochatonella verruculosa, produced a large salmon } \\
\text { mortality in the region. Later that year a harmful algal bloom develops, leaving Chiloé archipelago as a disaster } \\
\text { zone. }\end{array}$ & Buschmann et al. (2016) \\
\hline & $\begin{array}{l}\text { There is a controversy between forestry subsidies (USD } 1.9 \text { millions) and subsidies to manage and conserve the } \\
\text { native forests (USD } 84 \text { thousand). So, Eucalyptus spp. forests start replacing natural forests. }\end{array}$ & Frêne et al. (2014) \\
\hline & $\begin{array}{l}\text { Authors describe this period as experiencing fast changes in the use of land and sea, extraction of algae and } \\
\text { mosses (Sphagnum spp.), generation of industrial wind parks and unprecedented environmental changes such as } \\
\text { harmful algal blooms and droughts. }\end{array}$ & Elwell et al. (2018) \\
\hline & $\begin{array}{l}\text { During } 2007 \text { concern starts over peatland exploitation, which is generating increasing summer water crises. } \\
\text { Furthermore, wind parks have generated the destruction of peatlands. }\end{array}$ & $\begin{array}{l}\text { SERNAGEOMIN (2008), } \\
\text { Mondaca (2017) }\end{array}$ \\
\hline \multicolumn{3}{|c|}{ Social Subsystem } \\
\hline \multirow{3}{*}{$\begin{array}{l}\text { Bridge social } \\
\text { capital }\end{array}$} & $\begin{array}{l}\text { Salmon farming is an economic development concentrated on few enterprises, with weak connections with the } \\
\text { local economy, generating dependency among local citizens. The role of the Chilean state is described as } \\
\text { permissive, abandoning the community. }\end{array}$ & Cabello et al. (2018) \\
\hline & $\begin{array}{l}\text { In } 2008 \text { the law on coastal marine spaces for native people (ECMPO) enters into force, given the problems } \\
\text { between exploitation areas and indigenous communities. }\end{array}$ & Saavedra Gallo (2013) \\
\hline & $\begin{array}{l}\text { During the } 2016 \text { harmful algal bloom, the Chilean government provides financial compensations, which are } \\
\text { interpreted as the "typical" governmental response. }\end{array}$ & Thomas (2018) \\
\hline \multirow{5}{*}{$\begin{array}{l}\text { Cultural } \\
\text { capital and } \\
\text { identity }\end{array}$} & $\begin{array}{l}\text { Since the first ISA virus crisis, regional economic paradigms change, diversifying the economy toward no- } \\
\text { extractive activities such as tourism. }\end{array}$ & Barton and Fløysand (2010) \\
\hline & FAO declares Chiloé as Globally Important System of the world agricultural patrimony (GIAHS). & $\begin{array}{l}\text { "Agricultores de Chiloé } \\
\text { llaman a resguardar el } \\
\text { patrimonio agrícola local" } \\
(2015) \\
\end{array}$ \\
\hline & $\begin{array}{l}\text { Patrimonial tourism is proposed as a way to maintain the socioeconomic characteristics of communities in need } \\
\text { of support. }\end{array}$ & Sánchez et al. (2016) \\
\hline & During 2009, Chiloé occupies the third place of tourism destinies worldwide (Lonely Planet). & Ulloa and Del Valle (2014) \\
\hline & Scientists propose that tourists have a negative perception of aquaculture. & Outeiro et al. (2018) \\
\hline
\end{tabular}




\begin{tabular}{|c|c|c|}
\hline & During 2012, the patrimonial school of crafts is founded. & $\begin{array}{l}\text { "Al rescate del patrimonio } \\
\text { cultural intangible. La } \\
\text { escuela patrimonial de } \\
\text { artesanías y oficios de } \\
\text { lingue, Chiloé" }(2020)\end{array}$ \\
\hline \multirow{5}{*}{$\begin{array}{l}\text { Economic } \\
\text { capital }\end{array}$} & During 2007, the ISA virus crisis generates a salmon production crisis with socioeconomic consequences. & Gillet and Olate (2010) \\
\hline & $\begin{array}{l}\text { In June 2008, } 64 \text { million USD are lost reducing } 1000 \text { employments. Banks state that they will reconsider the } \\
\text { requirements to loan money to salmon farmers. }\end{array}$ & $\begin{array}{l}\text { Bustos (2015), Katz et al } \\
\text { (2011) }\end{array}$ \\
\hline & $\begin{array}{l}\text { The traditional community work is transformed into individual wage work. After enterprises closed, in } 2007 \text {, } \\
\text { people migrated from rural to urban areas increasing unemployment and/or accepting precarious jobs. }\end{array}$ & Lazo and Carvajal (2018) \\
\hline & In 2007 the milk products enterprise CHILOLAC enters into bankruptcy. & \begin{tabular}{|l|} 
"Declaran quiebra de \\
Chilolac. Banca privada y \\
trabajadores son los \\
principales acreedores de la \\
lechera" (2007) \\
\end{tabular} \\
\hline & $\begin{array}{l}\text { In } 2012 \text {, some authors propose that Chilote's dependency of the aquaculture sector has reduced their adaptation } \\
\text { capacity. }\end{array}$ & Barton et al. (2012) \\
\hline $\begin{array}{c}\text { Human } \\
\text { capital }\end{array}$ & $\begin{array}{l}\text { The ISA virus crisis had a profound effect on human capital. People returned to their original regions due to } \\
\text { unemployment, generating a perception of instability and distrust. }\end{array}$ & Zanlungo et al. (2015) \\
\hline \multirow{4}{*}{$\begin{array}{l}\text { Union social } \\
\text { capital }\end{array}$} & $\begin{array}{l}\text { During 2008, The New York Times TM published an article criticizing the practices conducting to the ISA virus } \\
\text { crisis. At this point, the crisis turned global. }\end{array}$ & Barton and Fløysand (2010) \\
\hline & $\begin{array}{l}\text { In 2013, two people die in Quellón, due to the precarious health conditions of the island. Social protests end after } \\
\text { negotiations with the central government and local authorities. }\end{array}$ & Arriagada (2016) \\
\hline & $\begin{array}{l}\text { During 2015, artisan fishermen were deeply affected by salmon farming, also feeling that the Chilean state did } \\
\text { not guarantee their activities. This condition generated Chilote's May during } 2016 \text {. }\end{array}$ & $\begin{array}{l}\text { Barton and Román (2016), } \\
\text { Valdebenito Allendes } \\
(2018)\end{array}$ \\
\hline & $\begin{array}{l}\text { The closure of fishing and aquaculture areas during May 2016, due to red tide events generates the social- } \\
\text { environmental crisis "Mayo Chilote". The government ends this crisis by offering monetary subsidies to } \\
\text { fishermen. }\end{array}$ & Cabello et al. (2018) \\
\hline
\end{tabular}

\section{REFERENCES}

Alcalde Silva, J. 2014. De los bienes y de su dominio, posesión, uso y goce. Revista Chilena de derecho privado, 23, pp. 391-397.

Altieri, M. A. and Rojas, A. 1999. Ecological impacts of Chile's neoliberal policies, with special emphasis on agroecosystems. Environment, Development and Sustainability 1(1):55-72.

Agricultores de Chiloé llaman a resguardar el patrimonio agrícola local. 16 de abril 2015. FAO in Chile. [online] URL: http://www.fao.org/chile/noticias/detail-events/en/c/283728/

Aguayo, B.E.C. and Barriga, J. 2016. Behind certification and regulatory processes: Contributions to a political history of the Chilean salmon farming. Global Environmental Change 39:81-90. 
Al rescate del patrimonio cultural intangible. La escuela patrimonial de artesanías y oficios de lingue, Chiloé. (s/f). Museo Nacional de Historia Natural. s/f. [online] URL: http://www.mnhn.cl/613/w3-article81180.html? noredirect $=1$

Altieri, M. A., \& Rojas, A. 1999. Ecological impacts of Chile's neoliberal policies, with special emphasis on agroecosystems. Environment, Development and Sustainability, 1:1, pp. 55-72.

Álvarez Abel, R. and Ther Ríos, F. 2016. Fragmentos de una cosmovisión mestiza asociada al acceso y uso del entorno costero en el Archipiélago de Chiloé. Diálogo andino 49(1):123-129.

Álvarez, R., Munita, D., Fredes, J., and Mera, R. 2008. La utilización de corrales de pesca en las fuentes históricas y recientes. Pages 143-170 in Álvarez, R., Munita, D., Fredes, J., and Mera, R. (Eds). Corrales de pesca en Chiloé. Imprenta América. Valdivia, Chile. [online] URL:

http://www.bibliotecanacionaldigital.gob.cl/bnd/645/w3-article-585024.html

Álvarez, C., Gajardo, C. and Ther, F. 2016. Actores y conflictos territoriales en una figura de administración pública de la pesca artesanal: El caso de la zona contigua en las regiones de Los Lagos y de Aysén, sur de Chile. Magallania (Punta Arenas) 44(1):131-147.

Amtmann, C.A., \& Blanco, G. 2001. Efectos de la salmonicultura en las economías campesinas de la Región de Los Lagos, Chile. Revista austral de ciencias sociales, 5, pp. 93-106.

Andrade, R.B. 2017. El contexto cultural de la papa en Chiloé. Colecciones Digitales, Subdirección de Investigación. Dirección de bibliotecas, archivos y museos (Dibam), 23 p.

Arenas, F., Andrade, B., \& Qüense, J. 2001. La valorización de un espacio periférico: el caso de la costa oriental de la Isla Grande de Chiloé. Revista de Geografía Norte Grande, 28, pp. 79-90.

Aros, F. and Marchant, C. 2018. Transformaciones en la identidad territorial en Chiloé desde la llegada de la industria salmonera: el caso de la localidad de Quemchi. Espacios 7(13):47-71.

Arriagada, N. 2016. Identidad y subjetivación política en el Movimiento por la salud digna en Chiloé. Polis. Revista Latinoamericana 44:1-21.

Avendaño, M., Cantillánez, M., Le Pennec, M., Varela, C. and Garcias, C. 2011. Distribución temporal de larvas de Mytilus chilensis (Hupé, 1954) (Mollusca: Mytilidae), en el mar interior de Chiloé, sur de Chile. Latin american journal of aquatic research 39(3):416-426.

Barrett, G., Caniggia, M. I. and Read, L. 2002. "There are more vets than doctors in Chiloé": social and community impact of the globalization of aquaculture in Chile. World Development 30(11):1951-1965.

Barros, A. 1980. Astillas de Chiloé. ¿Desarrollo regional o negocio particular? EURE. Revista Latinoamericana de Estudios Urbano Regionales, 6:18, pp. 37. 
Barton, J. R. and Fløysand, A. 2010. The political ecology of Chilean salmon aquaculture, 1982-2010: A trajectory from economic development to global sustainability. Global Environmental Change 20(4):739752.

Barton, J. R. and Román, Á. 2016. Sustainable development? Salmon aquaculture and late modernity in the archipelago of Chiloé, Chile. Island Studies Journal 11(2):651-672.

Barton, J., Román, Á., Salazar, A. and McPhee, B. 2012. ¿Son nuevas las ruralidades de Chiloé? transformaciones territoriales y la "modernización" de los modos de vida rurales. Anales de la sociedad Chilena de Ciencias Geográficas. El mundo rural y sus problemáticas, pp. 197-203.

Bermúdez Soto, J. 2010. Política y regulación ambiental de la acuicultura chilena. Revista de Derecho de la Pontificia Universidad Católica de Valparaíso 28:1:307-333.

Bravo Sánchez, J. M. 2004. La cultura chilota y su expresión territorial en el contexto de la globalización de la economía. Memoria para optar al Título Profesional de Geógrafo. Escuela de Geografía. Facultad de Arquitectura y Urbanismo. Universidad de Chile. 292 p.

Buschmann, A., Pizarro, R., and Doren, D. 2002. De pescadores a cultivadores del mar: Salmonicultura en Chile. Fundación Terram. Análisis de Políticas Públicas, 10-12 p.

Bustos, B. 2015. ¿Síndrome de Estocolmo? Comunidad, industria y desarrollo tras la crisis del virus ISA en Chiloé in Román, Á., Barton, J. R., Bustos, B.G. and Salazar, A. (Eds.). Revolución salmonera: paradojas y transformaciones territoriales en Chiloé, pp. 235-257. RIL editores.

Cabello, P., Torres, R. and Mellado, C. 2018. Conflicto socioambiental y contienda política: encuadres de la crisis ambiental de la marea roja en Chiloé (Chile). América Latina Hoy 79:81-102.

Cárdenas, R. and Villagrán, C. 2005. Chiloé: Botánica de la cotidianidad [relación del chilote con su entorno natural: plantas curativas, mágicas, alimenticias, tintóreas, madereras y artesanales]. Consejo Nacional del Libro y la Lectura. 365 p.

Carvajal, J. and González, L. 1990. Presencia de Hysterothylacium sp.(Nematoda: Anisakidae) en salmón coho de Chiloé cultivado en jaulas. Revista Chilena de Historia Natural 83:565-583.

Ceballos, A., Dresdner-Cid, J.D. and Quiroga-Suazo, M.Á. 2018. Does the location of salmon farms contribute to the reduction of poverty in remote coastal areas? An impact assessment using a Chilean case study. Food Policy 75(C):68-79.

Cereceda, L.E. and Dahse, F. 1980. Dos décadas de cambios en el agro chileno. Santiago: Cuadernos del Instituto de Sociología. Pontificia Universidad Católica de Chile. Primera parte: El orden social agrario tradicional. pp. 11-35. 
Claude, M., Oporto, J., Ibáñez, C., Brieva, L., Espinosa, P.C. and Arqueros, W.M. 2000. La ineficiencia de la salmonicultura en Chile: aspectos sociales, económicos y ambientales. Santiago: Terram Publicaciones. 72 p.

Coq-Huelva, D., Ther-Rios, F. and Bugueño, Z. 2018. Scalar Politics and the Co-Evolution of Social and Ecological Systems in Coastal Southern Chile. Tijdschrift voor economische en sociale geografie 109(3):34-448.

Daughters, A. 2009. Globalization Hits El Trauco: The Archipelago of Chiloé in the Era of Neoliberalism. Lost in the Long Transition: Struggles for Social Justice in Neoliberal Chile, pp. 97-113.

Daughters, A. 2016. Southern Chile's Archipelago of Chiloe: Shifting Identities in a New Economy. The Journal of Latin American and Caribbean Anthropology 21(2):317-335.

Declaran quiebra de Chilolac. Banca privada y trabajadores son los principales acreedores de la lechera. 31 de enero 2007. La Estrella - El Diario de Chiloé. [En línea]

http://www.laestrellachiloe.cl/prontus4 nots/site/artic/20070131/pags/2007013103235.html.

Delamaza, G., Robles, C., Montecinos, E. and Ochsenius, C. 2012. Redes de política pública y agendas de participación ciudadana en el Chile postransicional: ¿Desafiando la política o recreando sus límites? Gestión y política pública 21(1):45-86.

Díaz, M.F., Zegers, G. and Larraín, J. 2005. Antecedentes sobre la importancia de las turberas y el pompon en la Isla de Chiloé. Fundación Senda Darwin, 26. 34 p.

El gran auge de los choritos en Chiloé. 22 de octubre 2007. Millonarias inauguraciones de plantas de procesos y la creación de un PTI para el sector auguran un futuro auspicioso. La Estrella - El Diario de Chiloé. [online] URL: http://www.laestrellachiloe.cl/prontus4 nots/site/artic/20071022/pags/2007102207373.html

Elwell, T. L., Gelcich, S., Gaines, S. D. and López-Carr, D. 2018. Using people's perceptions of ecosystem services to guide modeling and management efforts. Science of The Total Environment 637:1014-1025.

Estay, M. and Chávez, C. 2015. Decisiones de localización y cambios regulatorios: el caso de la acuicultura en Chile. Latin american journal of aquatic research 43(4):700-717.

FAO, 2015. A world overview of species of interest to fisheries. Aulacomya ater. FIGIS species fact sheets. Text by Montserrat Ramón Species Identification and Data Programme- SIDP. FAO Fisheries and Aquaculture Department [online] URL: http://www.fao.org/fi/website

Fløysand, A. and Román, Á. 2008. Industria salmonera, sistemas de innovación y desarrollo local: el punto de vista de las municipalidades de Chiloé. Bergen: Departamento de Geografía, Universidad de Bergen. 100 p. 
Frêne, C., Ojeda, G., Santibáñez, J., Donoso, C., Sanzana, J., Molina, C., Andrade, P. and Núñez-Ávila, M. 2014. Agua en Chile: diagnósticos territoriales y propuestas para enfrentar la crisis hídrica. Santiago: Iniciativa Agua que has de Beber. $60 \mathrm{p}$.

Fryer, J.L., Lannan, C.N., Garcés, L.H., Larenas, J.J., and Smith, P.A. 1990. Isolation of a rickettsiales-like organism from diseased coho salmon (Oncorhynchus kisutch) in Chile. Fish pathology 25(2):107-114.

Gajardo Cortés, C. and Ther Ríos, F. 2011. Saberes y prácticas pesquero-artesanales: cotidianeidades y desarrollo en las caletas de Guabún y Puñihuil, isla de Chiloé. Chungará (Arica) 43:589-605.

Gajardo, P., Mondaca, E. and Santibáñez, P. 2017. La minería industrial como una nueva amenaza al espacio marino costero de Chiloé: Bahía de Cucao como caso de estudio. Revista Iberoamericana de Viticultura, Agroindustria y Ruralidad 10(3):110-138.

Gatica L. 2012. Análisis del D.L.701 referente al otorgamiento de bonificaciones para la forestación de suelos ñadi. Tesis Ingeniero en Conservación de Recursos Naturales. Universidad Austral de Chile, Facultad de Ciencias Forestales y Recursos Naturales, Valdivia, Chile. 22 p.

GESAM consultores. 2006. Diagnóstico de la acuicultura a pequeña escala en Chile. Informe Final. FIP 2004-26. 353 p. [online] URL: http://www.veterinaria.org/revistas/redvet/n101014.html

Gillet Infante, J.T. and Olate Campos, C. 2010. La crisis del salmón y el desempleo en la décima región. Seminario para optar al título de Ingeniero Comercial, mención economía. Escuela de Economía y Administración. Facultad de Economía y Negocios. Universidad de Chile.

Grenier, P. 1984. Chiloé et les chilotes: marginalité et dépendance en Patagonie Chilienne. Aix-en-Provence: Édisud.

Hormazábal Henríquez, J. 2006. Degradación espacial y temporal del bosque nativo, en el noreste de la Isla Grande de Chiloé, X región. Memoria para optar al Título Profesional de Geógrafo. Escuela de Geografía. Facultad de Arquitectura y Urbanismo. Universidad de Chile. 196 p.

Katz, J., Lizuka, M. and Muñoz, S. 2011. Creciendo en base a los recursos naturales, "tragedias de los comunes" $y$ el futuro de la industria salmonera chilena. CEPAL. $95 \mathrm{p}$.

Lazo, A. and Carvajal, D. 2018. La movilidad y el habitar chilote. Cambios, rupturas y continuidades en las prácticas de movilidad cotidiana de los habitantes del archipiélago de Chiloé, en el sur austral de Chile. Chungará (Arica) 50(1):145-154.

López, D. A., \& Buschmann, A. H. 1991. Acuicultura: Beneficios y riesgos de una actividad que se expande. Ambiente y Desarollo, 7, pp. 109-115.

Mancilla, L. and Mardones, L. 2010. El terremoto de 1960 en Castro. Ediciones La Tijera. Chile. 192 p.

Manns, P. 1972. Los Terremotos Chilenos. Editorial Quimantú, Santiago, Chile. Vol. 15. pp. 41-43. 
Mansilla Torres, S. 2006. Chiloé y los dilemas de su identidad cultural ante el modelo neoliberal chileno: la visión de los artistas e intelectuales. Revista Alpha (Osorno) 23:9-36.

Marín, A. and Gelcich, S. 2012. Gobernanza y capital social en el co-manejo de recursos bentónicos en Chile: aportes del análisis de redes al estudio de la pesca artesanal de pequeña escala. Cuhso. Cultura-hombresociedad 22(1):131-153.

Marino, M. 1985. Chiloé: economía, sociedad, colonización. Edición Víctor Naguil, Ancud. pp. 490-506.

Molinet, C., Lafon, A., Lembeye, G. and C. Moreno. 2003. Patrones de distribución espacial y temporal de floraciones de Alexandrium catenella (Whoedon and Kofoid) Balech, 1985, en aguas interiores de la Patagonia noroccidental de Chile. Revista Chilena de Historia Natural 76:681-698.

Mondaca, E. 2017. The Archipelago of Chiloé and the uncertain contours of its future: Coloniality, new extractivism and political-social re-vindication of existence in: Environmental Crime in Latin America (pp. 31-55). Palgrave Macmillan, London.

Montenegro, P. 2016. Alimentación e imaginarios sociales: Análisis del contexto alimentario de las localidades de Quilo, Calle y Quetalmahue, comuna de Ancud. Isla Grande de Chiloé. Tesis para optar al título de Antropólogo y al grado académico de Licenciado en Antropología. Facultad de Filosofía y Humanidades. Universidad Austral de Chile. 142 p.

Montero, C. 2004. Formación y desarrollo de un cluster globalizado: el caso de la industria del salmón en Chile (Vol. 145). United Nations Publications. 75 p.

Muñoz, J.L. 2006. Synopsis of salmon farming impacts and environmental management in Chile. World Wildlife Foundation, Valdivia, Chile, $88 \mathrm{p}$.

Oltremari, J. V. and Guerrero, X. 2003. Planificación participativa en áreas protegidas con comunidades indígenas: el caso del Parque Nacional Chiloé. Bosque (Valdivia) 24(2):69-78.

Ortiz, R., Párraga, M., Navarrete, J., Carrasco, I., de la Vega, E., Ortiz, M. and Blanchette, R. A. 2014. Investigations of biodeterioration by fungi in historic wooden churches of Chiloé, Chile. Microbial ecology 67(3):568-575.

Oseland, S. E., Haarstad, H. and Fløysand, A. 2012. Labor agency and the importance of the national scale: emergent aquaculture unionism in Chile. Political Geography 31(2):94-103.

Outeiro, L., Villasante, S. and Oyarzo, H. 2018. The interplay between fish farming and nature-based recreation tourism in Southern Chile: A perception approach. Ecosystem Services 32:90-100.

Oyarzún, C. E. and Huber, A. 1999. Balance hídrico en plantaciones jóvenes de Eucalyptus globulus y Pinus radiata en el sur de Chile. Terra latinoamericana 17(1):35-44. 
Quintanilla, V.G. 2004. Degradación del bosque pluvial en una cuenca hidrográfica del norte de la Isla Grande de Chiloé. Revista de Geografía Norte Grande, 31, pp. 73-84.

Ramírez, E., Modrego, F., Yáñez, R. and Macé, J. C. 2010. Dinámicas territoriales de Chiloé, del crecimiento económico al desarrollo sostenible. Documento de trabajo/Programa Dinámicas Territoriales Rurales. RIMISP Centro Latinoamericano para el Desarrollo Rural; no. 86.

Ramírez, E., Modrego, F., Macé, J. C., \& Yáñez, R. 2009. Caracterización de los actores de Chiloé Central. Documento de trabajo/Programa Dinámicas Territoriales Rurales. RIMISP-Centro Latinoamericano para el Desarrollo Rural; no. 55.

Saavedra Gallo, G. 2013. La artesanal en las encrucijadas de la modernización. Usos, apropiaciones y conflictos en el borde costero del sur de Chile. Revista andaluza de antropología 4:79-102.

Saldívar Arellano, J. M. 2017. "Chilote tenía que ser»: Vida migrante transnacional en territorios patagónicos de Chile y Argentina. Cultura-hombre-sociedad 27(2):175-200.

Salgado Reyes, R. 2005. Análisis del desarrollo de la salmonicultura chilena. Proyecto de título presentado en la Facultad de Agronomía e Ingeniería forestal, para obtener el título de Ingeniero Agrónomo. Pontificia Universidad Católica de Chile. 69 p.

Saliéres, M., Le Grix, M., Vera, W. and Billaz, R. 2005. La agricultura familiar chilota en perspectiva. Lider: revista labor interdisciplinaria de desarrollo regional 13:79-104.

San Carlos, A.C., Fernández, F.M., \& Gómez, D.U. 2018. Chicha de manzana de Chiloé: Historia épica de un producto típico, siglos XIX-XX. Revista estudios hemisféricos y polares, 9:2, pp. 1-24

Sánchez, M.J.B., Rubio, M.C.Q. and Sahady Villanueva, D.R. 2016. Molinos de agua de Chiloé. La supervivencia de una economía campesina en tiempos de globalización a través del turismo patrimonial, Región de los Lagos, Chile. Anales de la Sociedad Chilena de ciencias geográficas 1:27-33.

Sandoval, M., Parada, C. and Torres, R. 2018. Proposal of an integrated system for forecasting Harmful Algal Blooms (HAB) in Chile. Latin American Journal of Aquatic Research 46(2):424-451.

Sepúlveda, C. and Geisse, G. 1995. El caso de Golden Spring: la construcción social de la demanda ambiental entre los habitantes de Compu. Ambiente y Desarrollo 11(4):59-66.

SERNAGEOMIN (Servicio Nacional de geología y minería). 2008. Catastro y levantamiento geológico de reservas explotables del recurso turba en Chiloé, Región de Los Lagos. Gobierno regional de Los Lagos. Informe Final. 298 p.

Sfeir, R. 2005. Diagnóstico económico y social de la acuicultura en chile. Fondo de Investigación Pesquera (FIP) $N^{\circ}$ 2002-24. Subsecretaria de pesca. Informe final. VOLUMEN I y II. Coquimbo. [online] URL: http://www.fip.cl/FIP/Archivos/pdf/informes/inffinal,202002-24 
Sievers, G., Lobos, C., Inostroza, R., and Ernst, S. 1996. The effect of the isopod parasite Ceratothoa gaudichaudii on the body weight of farmed Salmo salar in southern Chile. Aquaculture 143(1):1-6.

Soto, D., Jara, F., \& Moreno, C. 2001. Escaped salmon in the inner seas, southern Chile: facing ecological and social conflicts. Ecological Applications, 11:6, pp. 1750-1762.

Thomas, E.H. 2018. Crisis and catastrophe on Chiloé: Collective memory and the (re) framing of an environmental disaster. Cultural Dynamics 30(3):199-213.

Torres, O. 2000. Impactos en la agricultura y la OMC. En: Globalización, Seattle y estrategias ciudadanas. Lom Ediciones, Santiago de Chile. pp. 27-30 in: Amtmann, C.A. and Blanco, G. 2017. Efectos de la salmonicultura en las economías campesinas de la Región de Los Lagos, Chile. Revista austral de ciencias sociales 5:93-106.

Ulloa, C. and Del Valle, C. D. 2014. Una mirada a la cultura en la isla de Chiloé (Chile) desde la lógica de la industria cultural. Tram[p]as de la Comunicación y la Cultura 77:5-16

Urbina, R. 1996. Castro, castreños y chilotes: 1960-1990. Ediciones Universitarias de Valparaíso de la Universidad Católica de Valparaíso. 354 p.

Valdebenito Allendes, J. 2018. I tweet, therefore I resist? Popular mobilization and social media in Chile: the case of Chiloe's red tide (2016). Izquierdas 40:185-201.

Yáñez Aguilar, C. 2011. De remeros a pasajeros: memorias de viajes y cambios sociales en una isla. Revista de Historia Regional y Local, 3, pp. 231-252.

Zanlungo, M., Pablo, J., Katz, J., \& Araya, G. 2015. Servicios intensivos en conocimiento en la industria salmonera chilena. Inter-American Development Bank. 61 p.

Zegers, G., Larraín, J., Díaz, M.F. and Armesto, J.J. 2006. Impacto ecológico y social de la explotación de pomponales y turberas de Sphagnum en la Isla Grande de Chiloé. Revista Ambiente y desarrollo 22(1):2834. 


\section{Appendix 2}

Social-ecological interview:

Purpose: Perception of the current phase of the adaptive cycle in Chiloé Island

Name:

Age: Place of birth:

Locality where you live:

Activity you develop:

The following questions relate to the four phases of the adaptive cycle theoretical model:

- Growth phase (r): the ecosystem (e.g. coastal zones) provides benefits (diversity of algae, seafood, fishes, and favorable conditions for mussel and salmon farming). People use them for subsistence and commerce (increasing their income). There is a change from traditional to industrial practices, the creation of cooperatives, and relationships between institutions and society.

- Conservation phase (K): the ecosystem remains without major changes and without modification of its uses. There are no new industries. There is a monopoly and rigid association rules. There are political and economic pressures from the global-national scale.

- Collapse phase ( $\Omega$ ): the ecosystem, due to internal and/or external perturbations, changes its structure. There is a disarticulation between social and ecological systems. The perturbations generate social and/or ecological crises, with economic consequences, emigration, and changes in productive activities.

- Reorganization phase ( $\boldsymbol{\alpha})$ : the system, after a perturbation, starts a new cycle. The ecosystem is different, and people adapt to it (e.g. new industries, the culture of new species).

Questions:

1. What is the current phase of the Chiloé Island social-ecological system?

2. What year did the phase start?

3. When did it end? or Does it continue?

4. Has the stated phase occurred before?

5. If the answer is yes, what was its approximate date? 